6-1-1997

\title{
Suspect Linkage: The Interplay of State Taxing and Spending Measures in the Application of Constitutional Antidiscrimination Rules
}

\author{
Dan T. Coenen \\ University of Georgia School of Law, coenen@uga.edu \\ Walter Hellerstein \\ University of Georgia School of Law, wallyh@uga.edu
}

D. SSRN

\section{Repository Citation}

Dan T. Coenen and Walter Hellerstein, Suspect Linkage: The Interplay of State Taxing and Spending Measures in the Application of Constitutional Antidiscrimination Rules (1997),

Available at: https://digitalcommons.law.uga.edu/fac_artchop/309

This Article is brought to you for free and open access by the Faculty Scholarship at Digital Commons @ University of Georgia School of Law. It has been accepted for inclusion in Scholarly Works by an authorized administrator of Digital Commons @ University of Georgia School of Law. Please share how you have benefited from this access For more information, please contact tstriepe@uga.edu. 


\title{
SUSPECT LINKAGE: THE INTERPLAY OF STATE TAXING AND SPENDING MEASURES \\ IN THE APPLICATION OF CONSTITUTIONAL ANTIDISCRIMINATION RULES
}

\author{
Dan T. Coenen* \\ and Walter Hellerstein**
}

\section{INTRODUCTION}

This article examines an important and recurring question that courts frequently resolve, but rarely analyze: whether taxing and spending measures should be viewed together when a state imposes a nondiscriminatory tax but also affords relief to some taxpayers through government spending. The answer to this question will often determine whether the state's actions violate constitutional strictures against discriminatory taxation. The taxing measure and the spending measure will generally pass muster if viewed in isolation. After all, courts rarely invalidate nondiscriminatory taxing measures on constitutional grounds. ${ }^{1}$ And true government spending measures, if considered alone, plainly fall outside the reach of constitutional restraints against discriminatory taxation. On the other hand, when taxing and spending measures are viewed together, they raise profound problems. In particular, the two measures often operate to produce precisely the result that the constitutional prohibitions against discriminatory taxation seek to

* Professor of Law, University of Georgia; B.S. 1974, University of Wisconsin; J.D. 1978, Cornell. - Ed.

** Professor of Law, University of Georgia; A.B. 1967, Harvard; J.D. 1970, University of Chicago. - Ed.

The authors would like to thank Amy L. Silverstein for her helpful comments on an earlier draft of this article.

1. To be sure, courts occasionally strike down state taxes for lack of sufficient nexus, see, e.g., Quill Corp. v. North Dakota, 504 U.S. 298 (1992), or because they are not fairly apportioned, see, e.g., Norfolk \& W. Ry. v. Missouri State Tax Commn., 390 U.S. 317 (1968), or because they fall directly on the federal government, see, e.g., United States v. Lohman, 74 F.3d 863 (8th Cir.), cert. denied, 116 S. Ct. 2549 (1996). But discrimination has been by far the most common basis for invalidation of state taxes on constitutional grounds, especially in recent years. 
avoid: the imposition of a greater burden in "practical effect" 2 on a constitutionally protected class of state taxpayers.

These questions arise in a wide variety of contexts. Invoking the Commerce Clause, taxpayers have attacked nondiscriminatory levies imposed on an industry when the state has made payments related to the tax or granted reductions in other taxes only to the extent that industry members engage in intrastate trade. ${ }^{3}$ Invoking the intergovernmental tax immunity doctrine, taxpayers have challenged nondiscriminatory exactions imposed on federal and state retirement income when the state simultaneously has awarded increased pension benefits to state retirees. ${ }^{4}$ And invoking uniformity and equality provisions of state constitutions, taxpayers have attacked nondiscriminatory property taxes when the government has granted credits against the tax that have produced nonuniform effective rates. 5

In each of these settings, the essential problem is the same: whether courts should view the state taxing and spending measures as an integrated whole or as independent components of the law for purposes of constitutional analysis. If the two measures are considered together, the entire scheme will violate the operative antidiscrimination rule, because payments made to the favored group will produce the prohibited disparity in effective tax burdens. If, on the other hand, the court considers the two measures separately, they will emerge unscathed from the constitutional attack.

In Parts I, II, and III of this article, we analyze cases that have raised these sorts of tax discrimination issues under the dormant Commerce Clause, the intergovernmental-tax-immunity doctrine, and state uniformity and equality provisions. In Part IV, we step back from the cases and propose a systematic approach, applicable

2. Complete Auto Transit, Inc. v. Brady, 430 U.S. 274, 279 (1977). See generally infra section IV.A.1.

3. See West Lynn Creamery, Inc. v. Healy, 512 U.S. 186 (1994); Maryland v. Louisiana, 451 U.S. 725 (1981); cf. American Trucking Assns. v. Scheiner, 483 U.S. 266, 304-05 (1987) (Scalia, J., dissenting) (considering linkage of simultaneous tax reforms; discussed infra notes 161-66).

4. See Sheehy v. Public Employees Retirement Div., 864 P.2d 762 (Mont. 1993); Ragsdale v. Department of Revenue, 895 P.2d 1348 (Or.), cert. denied, 116 S. Ct. 569 (1995).

5. See Westvaco Corp. v. South Carolina Dept. of Revenue, 467 S.E.2d 739 (S.C. 1995) (per curiam); Baker v. Matheson, 607 P.2d 233 (Utah 1979); State ex rel. La Follette v. Torphy, 270 N.W.2d 187 (Wis. 1978). The problem of unlawful linkage between taxing and spending measures can arise in a variety of other contexts as well. It may arise, for example, in the application of the Privileges and Immunities Clause. See infra notes 154-73 and accompanying text. It may also arise in the application of federal statutes that ban specific forms of discriminatory state taxation. See, e.g., Arizona Pub. Serv. Co. v. Snead, 441 U.S. 141 (1979) (construing 15 U.S.C. $\$ 391$, which bars discriminatory state taxation of the generation or transmission of electricity). 
in all these doctrinal settings, for determining whether courts should "link" taxing and spending measures when evaluating their constitutionality. As our analysis of the existing authorities will show, courts have failed to recognize the commonality of these cases and the subtlety of the questions they present. Instead, courts have resolved the cases in an ad hoc fashion, relying at best on the conclusory shibboleth that "substance" should triumph over "form." What the law needs is a more informative and principled framework for addressing this broad set of questions. In this article, we offer such a framework in the hope that it will help courts as they are forced to apply the now-impoverished "law of linkage."

\section{The Dormant Commerce Clause}

\section{A. The Nondiscrimination Principle}

Even absent preemptive congressional action, the Commerce Clause proscribes state laws that offend the Constitution's purpose of creating a "national common market." It is a "cardinal requirement"7 of this "dormant Commerce Clause" rule 8 that state taxes may not discriminate against interstate commerce. 9 Two cases from 1984 illustrate the operation of this constitutional requirement. In Bacchus Imports, Ltd. v. Dias, ${ }^{10}$ the Court struck down a Hawaii tax imposed on liquor wholesalers because it exempted sales of certain liquors manufactured in Hawaii. Similarly, in Westinghouse Electric Corp. v. Tully, ${ }^{11}$ the Court found the New York corporate income tax unconstitutional to the extent it afforded a credit solely for corporate export activities that occurred within the state. In Bacchus, Westinghouse, and many other cases, the Court has held state tax laws unconstitutional because "no State may discriminato-

6. Hunt v. Washington State Apple Adver. Commn., 432 U.S. 333, 350 (1977); see also C \& A Carbone, Inc. v. Town of Clarkstown, 511 U.S. 383, 410 (1994) (Souter, J., dissenting) (quoting Hunt).

7. New Energy Co. v. Limbach, 486 U.S. 269, 274 (1988).

8. Oklahoma Tax Commn. v. Jefferson Lines, Inc., 115 S. Ct. 1331, 1335 (1995).

9. See West Lynn Creamery, Inc. v. Healy, 512 U.S. 186, 199 (1994) ("[T] he cardinal principle [is] that a State may not 'benefit in-state economic interests by burdening out-of-state competitors."') (quoting New Energy, 486 U.S. at 273-274)). The Court has often recognized this principle in its decisions. See, e.g., Camps Newfound/Owatonna, Inc. v. Town of Harrison, 65 U.S.L.W. 4337, 4340 (U.S. May 19, 1997) (No. 94-1988). Bacchus Imports, Ltd. v. Dias, 468 U.S. 263, 268 (1984); Boston Stock Exch. v. State Tax Commn., 429 U.S. 318, 329 (1977); Northwestem States Portland Cement Co. v. Minnesota, 358 U.S. 450, 458 (1959).

10. 468 U.S. 263 (1984).

11. 466 U.S. 388 (1984). 
rily tax the products manufactured or the business operations performed in any other State."12

\section{B. Permissible Subsidization of Domestic Industry}

Just as the Court has consistently held that the Commerce Clause bars state taxes that favor in-state over out-of-state interests, so it has endorsed a countervailing principle that the Commerce Clause permits state spending that favors in-state over out-of-state interests. "Direct subsidization of domestic industry," a unanimous Court has declared, "does not ordinarily run afoul of [the dormant Commerce Clause] prohibition."13 The Court's explanation for this Commerce Clause dichotomy between state taxes that favor local interests and state subsidies that favor local interests is that " $[t]$ he Commerce Clause does not prohibit all state action designed to give its residents an advantage in the marketplace, but only action of that description in connection with the State's regulation of interstate commerce."14 Whatever difficulties this distinction may engender, 15 the Court has reached different conclusions on the constitutionality of domestic preference legislation depending on whether the preference takes the form of the exercise of the state's regulating or taxing power, on the one hand, or its spending power, on the other.

In New Energy Co. v. Limbach, ${ }^{16}$ the state sought to sidestep the rule condemning taxes that discriminate against interstate commerce by drawing upon the distinction between tax relief and affirmative state spending. At issue in the case was an Ohio motor fuel sales tax that provided the seller with a credit for all sales of ethanoli7 produced in the state, but not all sales of ethanol produced in other jurisdictions. Seeking to avert the dormant Commerce Clause ban on discriminatory taxation, the state argued that the credit was a "subsidy" that the state could direct as it wished to favored local ethanol suppliers. ${ }^{18}$

12. Boston Stock Exch, 429 U.S. at 337; see also Bacchus Imports, 468 U.S. at 271-73 (collecting early cases).

13. New Energy Co. v. Limbach, 486 U.S. 269, 278 (1988).

14. 486 U.S. at 278.

15. And we have traced them at length elsewhere. See Dan T. Coenen, Untangling the Market-Participant Exemption to the Dormant Commerce Clause, 88 MrCH. L. REv. 395 (1989); Walter Hellerstein \& Dan T. Coenen, Commerce Clause Restraints on State Business Development Incentives, 81 CORNELI L. REV. 789 (1996).

16. 486 U.S. 269 (1988).

17. Ethanol is a colloquial term for ethyl alcohol. It is typically made from corn and can be mixed with gasoline to produce a motor fuel called "gasohol."

18. See 486 U.S. at $277-78$. 
The Court accepted the major premise of this argument by recognizing that the Commerce Clause ordinarily does not proscribe subsidies for local industry. ${ }^{19}$ But the state's minor premise - that its tax credit involved such protected subsidization - did not fare as well. In the Court's eyes, the ethanol credit was caught up with "Ohio's assessment and computation of its fuel sales tax,"20 requiring the Court to consider the duty-imposing terms of the tax and its relief-granting credit provision together. From this perspective, it followed without difficulty that the tax was unconstitutionally discriminatory.

\section{West Lynn Creamery}

In West Lynn Creamery, Inc. v. Healy, ${ }^{21}$ decided six years after New Energy, the Court encountered another state effort to skirt the dormant Commerce Clause through invocation of a claimed power to subsidize. West Lynn Creamery involved a Massachusetts milk "pricing order" that, in substance, placed a tax on wholesale distributors for every local sale of milk, whether that milk was produced inside or outside the state. ${ }^{22}$ In addition, the order stipulated that all proceeds of the tax would go into a segregated fund that the state periodically would disperse solely to in-state milk producers (that is, local dairy farmers). ${ }^{23}$

The issue in the case was one of characterization. Did the pricing order, as Massachusetts argued, impose a permissible nondiscriminatory tax coupled with the sort of "subsidization of domestic industry" approved in New Energy, ${ }^{24}$ or did it embody a tax, coupled with de facto tax relief for local industry, in violation of the Court's well-settled antidiscrimination rule?25 This characterization issue sharply divided the Court, with Justice Stevens writing for a five-Justice majority; Justice Scalia, joined by Justice Thomas, concurring in the judgment; and Chief Justice Rehnquist, joined by Justice Blackmun, writing in dissent.

19. See 486 U.S. at 278.

20. 486 U.S. at 278.

21. 512 U.S. 186 (1994).

22. 512 U.S. at 190-91.

23. See 512 U.S. at 191. Under limited circumstances, portions of the fund would not be paid to producers; such undistributed funds would simply be returned to milk dealers, thus effectively reducing their total tax burden. See 512 U.S. at 191 n.8.

24. 512 U.S. at 199 n.15 (quoting New Energy, 486 U.S. at 278).

25. See 512 U.S. at 199. 
For the majority, the discriminatory-tax label "clearly" fit. ${ }^{26}$ In so ruling, the majority assumed that either an evenhanded milk tax or a state's outright payment of cash subsidies to local dairy farmers would be constitutional "standing alone." 27 But, in the majority's eyes, the tax and subsidy did not operate in isolation. Rather, the Court focused on the program "as a whole" 28 and found that the subsidy payments in effect were "rebates" or "refunds" of the tax. ${ }^{29}$ Accordingly, the Massachusetts scheme was unconstitutional because, like a protective tariff, it allowed "Massachusetts dairy farmers who produce at higher cost to sell at or below the price charged by lower cost out-of-state producers." 30

In a concurring opinion, Justice Scalia faulted Justice Stevens for writing so broadly as to imperil the constitutionality of virtually all state business subsidy programs. ${ }^{31}$ Justice Scalia acknowledged that a local-industry-favoring " 'exemption' from or 'credit' against a 'neutral' tax" would offend the ban on discriminatory taxation. . $^{32}$ $\mathrm{He}$ also asserted, however, that "not . . . every state law which obstructs a national market violates the Commerce Clause,"33 and that, in particular, there was no constitutional problem with a "subsidy for the in-state members of the industry" even if it was coupled with "nondiscriminatory taxation of the industry." 34 For Justice Scalia, the determinative issue was straightforward: Which of these two competing principles controlled the case? ${ }^{35}$

Although Justice Scalia thought the question was "close,"36 he joined the majority in concluding that Massachusetts had engaged in "discriminatory taxation" because the pricing-order payments constituted "rebates" of the pricing-order tax. ${ }^{37}$ This was true in Justice Scalia's view, however, only because the payments came out of a "segregated fund" created with the proceeds of the tax. ${ }^{38} \mathrm{Had}$ the taxes gone into "the State's general revenue fund," the pay-

26. 512 U.S. at 194.

27. 512 U.S. at 199.

28. 512 U.S. at 201.

29. 512 U.S. at 195-97 \& n.10.

30. 512 U.S. at 195.

31. See 512 U.S. at 207-09 (Scalia, J., concurring in the judgment).

32. 512 U.S. at 211.

33. 512 U.S. at 207.

34. 512 U.S. at 210.

35. See 512 U.S. at 211.

36. 512 U.S. at 211.

37. 512 U.S. at $210-11$.

38. 512 U.S. at 210 . 
ments made to in-state dairy farmers would not have constituted a "discriminatory refund" but instead would have qualified as the sort of affirmative subsidization approved by the Court in $\mathrm{New}$ Energy. 39

The dissenters challenged both the majority and concurring opinions. Emphasizing that the state tax fell exclusively on milk dealers while the subsidy favored milk producers, Chief Justice Rehnquist could find no constitutional problem at all in the Massachusetts program. Instead, for the dissenters, the program embodied an "evenhanded" 40 tax and the sort of subsidy for a favored industry group that the Court had approved in "case after case." 41

\section{A Short Analysis}

West Lynn Creamery, like many cases involving linkage issues, is subject to serious criticism on its own terms. In this section - as in similar sections in Parts II and III of this article - we offer such a critique. We do so, however, not merely to point out the analytical flaws in the opinions in the case, but, more important for present purposes, to demonstrate the need for the principled approach to the linkage question that we offer in Part IV.

The issue in West Lynn Creamery was whether the Court should view the Massachusetts milk dealer tax and producer subsidy independently or instead consider the tax and subsidy as parts of an integrated whole, thus rendering the Massachusetts program a de facto discriminatory tax. Justice Scalia embraced the latter position by reasoning that the subsidies were equivalent to tax "rebates," but found this characterization apt only because they came out of a segregated fund. This analysis is problematic, however, as a matter of both form and substance. It is problematic as a matter of form because the characterization of payments as rebates has nothing to do with their extraction from a segregated fund; rather, a rebate, which is nothing more than "a return of a part of a payment,"42 typically comes out of the same general revenue fund into which rebated income, property, or other taxes previously have been paid. Justice Scalia's analysis is problematic as a matter of substance as well because, in his view, only the slightest legislative alteration

39. 512 U.S. at 211.

40. 512 U.S. at 214 (Rehnquist, C.J., dissenting).

41. 512 U.S. at 213 (Rehnquist, C.J., dissenting).

42. Webster's Ninth New Colleglate Dictionary 981 (1986). 
would have cured the Massachusetts program's constitutional infirmity. Following Justice Scalia's logic, Massachusetts could have imposed the same taxes in the same amounts on the same milk dealers, and paid the same subsidies in the same amounts to the same milk producers, if only the state had run the tax payments into, and the subsidies back out of, the state's general fund..$^{43}$

In light of these troublesome points, it is not surprising that the majority eschewed Justice Scalia's pivotal "segregated fund" distinction. Instead, the majority deemed the "tax rebate" label applicable because the legislative dynamics that produced the tax-andsubsidy program were no different from those that produce commerce-impeding taxes paired with unconstitutional residentfavoring exemptions or credits. Thus,

when a nondiscriminatory tax is coupled with a subsidy to one of the groups hurt by the tax, a state's political processes can no longer be relied upon to prevent legislative abuse, because one of the in-state interests [that is, local dairy farmers] which would otherwise lobby against the tax has been mollified by the subsidy. 44

In other words, the "tax rebate" label fit because oppressive taxation of nonresident businesses was as likely to result from the simultaneous consideration of a general tax and a local-producerfavoring subsidy as from the simultaneous consideration of a general tax and a local-producer-favoring exemption or credit.

The majority opinion, like the concurrence, is susceptible to serious criticism. A fundamental difficulty with the majority's logic lies in its basic premise. The underlying assumption seems to be that what renders the ordinary local-business-favoring tax break constitutionally odious is its contemporaneous enactment with an otherwise "neutral" tax that burdens interstate as well as intrastate commerce. But this assumption is misplaced because many tax breaks invalidated by courts have been adopted long after enactment of the "neutral" tax from which the tax break affords discriminatory relief. ${ }^{45}$ Indeed, in New Energy itself, the fuel sales tax had been on the books for many years before the Ohio legislature adopted the ethanol-production sales tax credit that favored local

43. Cf. Cumberland Farms, Inc. v. Mahany, 943 F. Supp. 83, 87-88 (D. Me. 1996) (relying in part on Justice Scalia's concurrence in sustaining "nonintegrated" tax-and-subsidy scheme similar to the scheme at issue in West Lynn Creamery except that, among other things, subsidies were paid out of a general fund).

44. West Lynn Creamery, 512 U.S. at 200.

45. See, e.g., Bacchus Imports, Ltd. v. Dias, 468 U.S. 263, 265 (1984) (noting that liquor tax was enacted in 1939, while discriminatory exemptions took effect in 1971 and 1976); Boston Stock Exch. v. State Tax Commn., 429 U.S. 318, 319 (1977) (noting that state legislature, in 1968, enacted a discriminatory exemption to tax imposed since 1905). 
industry and rendered the overall taxing scheme invalid. ${ }^{46}$ Put differently, under the Court's dormant Commerce Clause precedents, it is the fact of the discrimination - rather than its timing - that renders resident-favoring tax relief provisions unconstitutional. Given this principle, it seems odd that the West Lynn Creamery majority so readily deemed the state's timing in adopting the subsidy of central significance in finding a constitutional violation. 47

A second problem with the majority's analysis in West Lynn Creamery lies in its failure to respond to the central criticism leveled by the dissent. As we have seen, the majority found that the Massachusetts program violated the Commerce Clause ban on discriminatory taxation because, in its view, the milk-producer payments were easily characterized as tax "rebates." 48 As a matter of common usage, however, tax rebates and refunds are paid out to the same person who previously paid the rebated or refunded tax..$^{49}$ Yet under the Massachusetts pricing order - as the dissenters took pains to emphasize - "the nondiscriminatory tax levied against all milk dealers [was] coupled with a subsidy to milk producers." 50 Given this feature of the Massachusetts program, it was not at all clear why the majority could so comfortably assert that the "rebate" or "refund" label was apt.

Although the majority and concurring opinions in West Lynn Creamery are subject to additional criticisms, ${ }^{51}$ the foregoing discussion suffices to make three key points. First, in applying the Commerce Clause prohibition on discriminatory taxation, courts will confront important questions about whether they should treat subsidies as freestanding exercises of the state's spending power, on the one hand, or as tax credits or exemptions, on the other. Second, the difficult task of answering these questions must for now proceed unguided by any well-developed jurisprudential theory offered by the Supreme Court. Finally, the conflicting and unsatisfying opinions in West Lynn Creamery signal the difficulties that beset this

46. See New Energy Co. v. Limbach, 486 U.S. 269, 272 (1988).

47. We will see in due course that the state's contemporaneous adoption of the tax and the subsidy does help justify the result in West Lynn Creamery. See infra notes 223-39 and accompanying text. The Court, however, never paused to offer an adequate explanation or indeed any explanation - of why this was the case.

48. See 512 U.S. at 197.

49. See Ballentine's LaW Dictionary 1062 (3d ed. 1969) (defining "rebate" as "[a] giving back"); see also supra note 42 and accompanying text.

50. 512 U.S. at 214 (Rehnquist, C.J., dissenting).

51. See Dan T. Coenen, Business Subsidies and the Dormant Commerce Clause (1996) (unpublished manuscript, on file with authors). 
area of the law and the need for bringing to it a more coherent approach.

\section{The Intergovernmental Tax Immunity Doctrine}

\section{A. The Nondiscrimination Principle}

The dormant Commerce Clause is not the only limit on state taxing powers designed to advance constitutional interests in nationalism. Another restriction lies in the so-called "doctrine of intergovernmental tax immunity."52 Beginning with its seminal ruling in $M^{\prime}$ Culloch v. Maryland, ${ }^{53}$ the Court repeatedly has insisted that the Constitution bars state taxes that discriminate against the federal government..$^{54}$ More recently, Congress has implemented this tax-immunity principle in a number of federal statutes, including 4 U.S.C. $\S 111.55$ Codifying the holding of a previous Supreme Court decision, $\S 111$ authorizes state taxation of "pay or compensation" of federal employees, but only "if the taxation does not discriminate against the [federal] employee because of the source of the pay or compensation." 56 This express statutory ban on state tax

52. Davis v. Michigan Dept. of Treasury, 489 U.S. 803,810 (1989). Although the doctrine still goes by this name, it may more accurately be characterized today as the doctrine of federal immunity from state taxation. The reciprocal character of the immunity, which was first articulated in Collector v. Day, 78 U.S. (11 Wall.) 113 (1871) (invalidating federal income tax on salary of state judge), and applied over much of the next seven decades, has been reduced almost to the point of nonexistence in the Court's modern decisions. See, e.g., South Carolina v. Baker, 485 U.S. 505 (1988) (holding that intergovernmental tax immunity doctrine does not bar federal income taxation of state and local bond interest); Massachusetts v. United States, 435 U.S. 444 (1978) (holding that intergovernmental tax immunity doctrine does not bar federal excise tax on state police helicopter); Helvering v. Gerhardt, 304 U.S. 405 (1938) (holding that intergovernmental tax immunity doctrine does not bar federal income tax on wages of most state employees).

53. 17 U.S. (4 Wheat.) 316 (1819).

54. See, e.g., United States v. New Mexico, 455 U.S. 720, 732 (1982). Apart from its antidiscrimination component, the tax-immunity doctrine operates to invalidate state taxes that place a "direct burden" on the federal government or its instrumentalities. 455 U.S. at 732 (internal quotation marks omitted) (quoting James v. Dravo Contracting Co., 302 U.S. 134, 150 (1937) (quoting Willcuts v. Bunn, 282 U.S. 216, 225 (1931))). This separate aspect of the tax-immunity principle is not implicated by the analysis set forth here.

55. Analogous statutes include 12 U.S.C. $\S 548$ (1994) (authorizing only nondiscriminatory state taxes on national banks) and 31 U.S.C. $\$ 3124$ (1994) (authorizing only nondiscriminatory franchise taxes on federal obligations). The application of these statutes can and will present exactly the same sort of linkage conundrums raised by 4 U.S.C. $\S 111$.

56. 4 U.S.C. $\S 111$ (1994). The Supreme Court holding codified in 4 U.S.C. $\$ 111$ was that of Graves v. New York ex rel. O'Keefe, 306 U.S. 466 (1939) (overruling line of cases that exempted federal employees from nondiscriminatory state taxation). As the Court later explained in Davis v. Michigan Department of Treasury, 489 U.S. 803, 812 (1989):

By the time the statute was enacted ... the decision in Graves had been announced, so the constitutional immunity doctrine no longer proscribed nondiscriminatory state taxation of federal employees. In effect, § 111 simply codified the result in Graves and foreclosed the possibility that subsequent judicial reconsideration of that case might reestablish the broader interpretation of the immunity doctrine. 
discrimination has given rise to linkage questions no less intriguing than those that mark the Supreme Court's dormant Commerce Clause decisions.

These linkage questions have their immediate origin in Davis $v$. Michigan Department of the Treasury. ${ }^{57}$ In Davis, a federal retiree challenged a state statute that excluded from state income taxation retirement payments made to former state - but not federal employees. Focusing on the statute's outright favoritism of state over federal pensioners, an eight-Justice majority struck down the taxing scheme as violative of the intergovernmental tax immunity doctrine.

Justice Stevens wrote a strong dissent. ${ }^{58}$ In his view, because the state treated federal employees like all but "a small percentage" 59 of "ordinary residents of the State,"60 there existed in Davis precisely the sort of "political check against abuse of the taxing power" that was lacking in past decisions applying the intergovernmental tax immunity doctrine. ${ }^{61}$ Building on this theme, Justice Stevens added:

Even if it were appropriate to determine the discriminatory nature of a tax system by comparing the treatment of federal employees with the treatment of another discrete group of persons, it is peculiarly inappropriate to focus solely on the treatment of state governmental employees. The State may always compensate in pay or salary for what it assesses in taxes. ... It trivializes the Supremacy Clause to interpret it as prohibiting the States from providing through this limited tax exemption what the State has an unquestionable right to provide through increased retirement benefits. ${ }^{62}$

In other words, Justice Stevens claimed that (1) a state generally may give former state employees additional retirement payments free from intergovernmental tax immunity constraints, and (2) the award of a tax exemption to state retirees constituted an additional payment for purposes of this principle. ${ }^{63}$

The majority did not question the first of these propositions, but it rejected any suggestion that the difference between a tax exemp-

57. 489 U.S. 803 (1989).

58. 489 U.S. at 818 (Stevens, J., dissenting).

59. 489 U.S. at 821 .

60. 489 U.S. at 824.

61. 489 U.S. at 820 (internal quotation marks omitted) (quoting United States v. County of Fresno, 429 U.S. 452, 463 (1977)).

62. 489 U.S. at 824.

63. Following his appointment to the Court, Justice Thomas expressed agreement with Justice Stevens's Davis dissent. See Barker v. Kansas, 503 U.S. 594, 605 (1992) (Stevens, joined by Thomas, JJ., concurring). 
tion and a benefit increase was legally inconsequential. There was a difference between the two forms of state action, in the majority's view, because

[i]n order to provide the same after-tax benefits to all retired state employees by means of increased salaries or benefit payments instead of a tax exemption, the State would have to increase its outlays by more than the cost of the current tax exemption, since the increased payments to retirees would result in higher federal income tax payments in some circumstances. 64

The Court went on to observe that " $[t]$ axes enacted to reduce the State's employment costs at the expense of the federal treasury are the type of discriminatory legislation that the doctrine of intergovernmental tax immunity is intended to bar."65

As we shall see, the Court's distinction between payments and tax exemptions based on their susceptibility to federal income taxation is highly problematic. ${ }^{66}$ A more satisfactory explanation of the decision may be that the Court in Davis, as in New Energy, focused on the very terms of the statutory pronouncement the state legislature itself had crafted. On this view, because the Michigan statute on its face provided a tax exemption that rendered the actual tax obligations of former state and federal employees unequal, the state violated the mandate that state "taxation ... not discriminate against the ... [federal] employee." 67

\section{B. The Post-Davis Intergovernmental Tax Immunity Cases}

The Court's decision in Davis unleashed a nationwide outpouring of litigation in which federal retirees asserted that state taxing schemes violated the intergovernmental tax immunity rule. State legislatures, duty-bound after Davis to remove provisions favoring state over federal retirees from their taxing systems, went to work as well. Two obvious cures for the malady were available, but each was painful. First, state legislators could eliminate the exemption afforded state employees. This response, however, was sure to raise a hue and cry - and dim the electoral appeal of incumbents among the politically potent voting bloc made up of all former and current state employees. Alternatively, state legislators could

64. 489 U.S. at 815 n.4.

65. 489 U.S. at 815 n.4.

66. See infra notes 208-22 and accompanying text.

67. 4 U.S.C. $\$ 111$ (1994) (emphasis added); see Davis, 489 U.S. at 814 (noting that it is "undisputed that Michigan's tax system discriminates in favor of retired state employees and against retired federal employees" before turning to Michigan's defense of its "inconsistent treatment of Federal and State Govemment retirees"). 
extend the retirement income exemption afforded state retirees to federal retirees as well. But this response was likely to generate limited political capital for lawmakers, while forcing them to lay new tax burdens on (or reduce services to) other vocal constituents. ${ }^{68}$

Faced with this dilemma, the legislatures of two states came up with an imaginative response. In both Montana and Oregon, lawmakers removed any facial discrimination in the tax statute itself by repealing the exemption for state retirement income. To placate newly taxed state-retiree constituents, however, these legislatures simultaneously provided for increased retirement payments. 69

Not surprisingly, former federal employees - who ended up in exactly the same taxpaying position they had occupied prior to Davis - attacked these legislative gambits. In essence, they argued that the increased benefit payments afforded state retirees constituted "rebates" or "refunds" of the new state taxes laid on state retirees by reason of the repeal of their preexisting tax exemption. For this reason, the federal-retiree plaintiffs argued, the Montana and Oregon schemes continued to violate the "mandate of equal treatment"70 imposed on states by Davis.

In Sheehy v. Public Employees Retirement Division, ${ }^{71}$ the Montana Supreme Court found the legislature's new-tax-and-newbenefits response to Davis unconstitutional. In Ragsdale $v$. Department of Revenue, 72 on the other hand, the Oregon Supreme Court found the legislature's use of this strategy permissible. This disparity in results, in cases so similar, underscores the difficulty of deciding whether ostensible exercises of the state spending power should be characterized as "rebates" for purposes of constitutional prohibitions on discriminatory taxation.

\section{Sheehy}

In Sheehy, the Montana Supreme Court considered whether the state violated section 111 when it awarded an "annual retirement adjustment payment" to state retirees at the same time it repealed

68. Extension of the exemption to federal retirees was likely to yield limited political returns because many federal retirees would view the reform as the result of judicial intervention, rather than of freely chosen legislative action, in that the action came only after the Supreme Court's decision in Davis.

69. See infra notes 71-91 and accompanying text.

70. Davis, 489 U.S. at 818.

71. 864 P.2d 762 (Mont. 1993).

72. 895 P.2d 1348 (Or.), cert. denied, 116 S. Ct. 569 (1995). 
its tax exemption for state retirement income. ${ }^{73}$ In ruling that the state's program was unlawful, the court deemed it dispositive that the added retirement benefit was "intended to make up, in part," for the new tax liability placed on state retirees. ${ }^{74}$ This finding was supported by three key facts. First, the equalization of retiree tax burdens and the increase in state retiree benefits were "included in and part of the same bill" enacted immediately in the wake of Davis. ${ }^{75}$ Second, the benefit adjustment was given only to resident retirees - who alone, under then-existing state law, were subject to the newly created tax liability - rather than to "all ... retirees," including nonresidents, "in recognition of their years of public service."76 Third, the retirement benefit adjustments - unlike prior grants of additional retirement payments - were to be paid out of the general revenues rather than out of the state's separate retirement fund. ${ }^{77}$

Under these circumstances, the court ruled that the newly created adjustment was "not an actual and legitimate pension or retirement benefit,"78 but instead a "partial tax rebate denominated otherwise in an attempt to evade the requirements of federal law."79 As a result, the court found that Montana's award of the new benefits violated the intergovernmental tax immunity doctrine no less than the discriminatory exemption of state retiree income outlawed in Davis itself. ${ }^{80}$

\section{Ragsdale}

In Ragsdale, the Oregon Supreme Court confronted the same sort of tax-equalization/benefit-increase response to Davis that

73. Sheehy, 864 P.2d at 764.

74. 864 P.2d at 768.

75. 864 P.2d at 767.

76. 864 P.2d at 768.

77. See 864 P.2d at 768.

78. 864 P.2d at 768.

79. 864 P.2d at 768; see also 864 P.2d at 769 ("The disparate treatment is based entirely on the State's desire to continue to provide an advantage to those of its own retirees losing a pre-Davis advantage ....").

80. There were two opinions apart from the majority opinion. In the first, Judge Rapkoch (joined by Justice Trieweiler) agreed that "the adjustment ... constitutes discriminatory taxation," because it was part of "a byzantine effort to avoid Davis." 864 P.2d at 77172 (Rapkoch, J., specially concurring in part and dissenting in part). However, Judge Rapkoch disagreed with the majority as to the severability of the benefit-adjustment provision from the remainder of the reformatory statute. In the other separate opinion, Judge Weber - the sole dissenter on the $\S 111$ issue - reasoned that the benefit adjustment was a permissible "increase in pay" that the state could grant - regardless of its inclusion with the tax exemption repeal - for the purpose of discouraging state retirees from moving out of state. 864 P.2d at 774-75 (Weber, J., specially concurring and dissenting). 
sparked the Montana Supreme Court's decision in Sheehy. In a 5-2 decision, however, the Oregon Supreme Court rebuffed the intergovernmental tax immunity challenge by refusing to characterize the payment increase to state retirees as "in effect, a tax rebate or tax benefit."81 In reaching this result, the court distinguished Sheehy on two grounds. First, unlike the benefit adjustments in Sheehy, Oregon's benefit increases were not limited to state residents. Instead, they were payable to all former state employees, including retirees who had relocated outside the state. Second, the new benefits were not drawn from the general treasury, but instead came out of the same state retirement fund from which other retirement benefits had been paid in the past. 82

The court in Ragsdale also emphasized that "there is no mathematical correlation between taxes and the [new] benefits created," 83 which instead were calculated solely "on an employee's years of service." 84 Thus, "[s]ome state retirees who will be required to pay state income taxes on their ... retirement benefits will receive no additional benefits under the ... law," while "some state retirees who will pay no state income taxes will receive additional benefits." 85 The court found it noteworthy as well that the added benefits - unlike true state tax exemptions - were subject to state and federal taxation. ${ }^{86}$

In sum, according to the Ragsdale majority, "[i]ntergovernmental tax immunity ... is concerned with discriminatory tax treatment." 87 The added benefits, however, were not a "tax rebate or tax benefit," 88 but instead reflected the State's effort "to fix the level of its employees' compensation" 89 by way of the "expenditure of trust funds." 90 The court stressed that such spending decisions are "subject to a watchful electorate that includes a vast majority of people who are not state employees." 1

81. Ragsdale v. Department of Revenue, 895 P.2d 1348, 1353 (Or.), cert. denied, $116 \mathrm{~S}$. Ct. 569 (1995).

82. See 895 P.2d at 1356.

83. 895 P.2d at 1350.

84. 895 P.2d at 1350 .

85. 895 P.2d at 1350.

86. See 895 P.2d at 1355; see also 895 P.2d at 1354, 1357.

87. 895 P.2d at 1353 (emphasis added).

88. 895 P.2d at 1354.

89. 895 P.2d at 1357.

90. 895 P.2d at 1354 .

91. 895 P.2d at 1357. 


\section{Some Shortcomings in the Ragsdale Analysis}

As in section I.D, we offer the following critique of Ragsdale not merely to point out the analytical flaws in the opinion, but, more important for present purposes, to demonstrate the need for the principled approach to the linkage question that we offer in Part IV.

The Oregon statute, as the court observed in Ragsdale, "contains indicia that could lead one to conclude either that the "benefits' are a kind of tax rebate or that the 'benefits' are compensation." 92 The issue presented to the court was whether the "rebate" label or the "compensation" label was more apt. Whatever the proper resolution of this issue, the majority's analysis in the Ragsdale case is marked by several analytical shortcomings.

First, there exists a basic flaw in the Ragsdale court's attempt to distinguish Sheehy on the twin grounds that the Montana benefits (unlike the Oregon benefits) were paid (1) only to resident retirees and (2) from the state's general treasury rather than from the retirement fund. The difficulty is that the court in Sheehy did not seem to find these considerations important in and of themselves; rather the Montana court focused on these facts because they supported a more general and case-dispositive finding that the legislature had adopted the payment increase for the very purpose of offsetting the newly imposed tax..$^{93}$ In Ragsdale, however, this point was never even contested. Rather, the court recognized, without any controversy at all, that the legislature had "increased ... retirement benefits to compensate state retirees, in part, for their increased income tax obligations."94 Thus, the Ragsdale court's

92. 895 P.2d at 1353-54.

93. See Sheehy v. Public Employees Retirement Div., 864 P.2d 762, 768 (Mont. 1993).

94. Ragsdale, 895 P.2d at 1352. The two grounds on which the Ragsdale court attempted to distinguish Sheehy are questionable for other reasons as well. First, the court sought to differentiate Sheehy by pointing out that Oregon had afforded identical treatment to resident and nonresident retirees, whereas Montana had limited its benefit payment to former state employees who continued to reside in Montana. This distinction, however, seems shaky because the intergovernmental immunity doctrine is designed to assure equality between state and federal interests, not between residents and nonresidents. See Gilson v. Department of Treasury, 544 N.W.2d 673 (Mich. Ct. App. 1996) (holding that neither Davis nor the intergovernmental immunity doctrine precludes states from taxing the retirement income of former employees of other states while exempting the retirement income of their own former employees); Harmon v. Director of Revenue, 894 S.W.2d 154 (Mo. 1995) (same); Alarid v. Secretary of the N.M. Dept. of Taxation \& Revenue, 878 P.2d 341 (N.M. Ct. App. 1994) (same), cert. denied, 513 U.S. 1081 (1995). Simpson v. Department of Revenue, 870 P.2d 824 (Or. 1994) (per curiam) (same). In addition, this distinction provides a potentially easy means of evading the underlying principle of Sheehy, at least if the great majority of state retirees continue to live in the same state where they worked as public employees.

Second, the Ragsdale court's distinguishing of Sheehy on the ground that the additional benefit payments in that case came from the general treasury, rather than from the segre- 
attempt to distinguish Sheehy - while built on an understandable identification of factual differences - fails to take account of the essential reasoning of the Montana court. Indeed, attaching the tax-relief label to the new Oregon benefits seemed even more appropriate than in Sheehy because the Oregon legislature had specifically provided that the increased retirement benefits would be paid only so long as state retiree income remained taxable. ${ }^{95}$

More problematic than the Ragsdale court's questionable success in distinguishing Sheehy was its failure even to mention the Supreme Court's freshly minted decision in West Lynn Creamery. ${ }^{96}$ In West Lynn Creamery, after all, the Court had emphatically insisted on looking at the practical effect of a tax and spending mandate "as a whole."97 The Ragsdale majority, however, drove an analytical wedge between the state's decision to treat state retirement payments as taxable income - which the court found unobjectionable because it simply extended Oregon's nondiscriminatory personal income tax to state retirement benefits - and the state's simultaneous award of cash payments limited to state retirees which the court deemed unobjectionable because those payments constituted permissible state "expenditures." 98

West Lynn Creamery also undermines the effort of the majority in Ragsdale to defend the extra retirement benefit by comparing that payment increase to a legislative decision made in a later year to give retirees a cost-of-living adjustment. ${ }^{99}$ After all, the majority in West Lynn Creamery found a problem of constitutional policy

gated retirement fund, is weak because both the retirement fund and the general treasury were funded by general tax revenues. To be sure, the increased benefits in Ragsdale were funded by employer contributions to the Oregon Public Employees Retirement System. See 895 P.2d at 1356. These employers, however, were "the State ... and ... its political subdivisions and instrumentalities," 895 P.2d at 1349 n.2, which presumably derive their funds including the funds used to make contributions to the Oregon Public Employees Retirement System - in large measure from tax revenues. Indeed, according to Justice Scalia's logic in West Lynn Creamery, the payment of increased benefits from the segregated retirement fund may have rendered Oregon's program more constitutionally problematic than the program at issue in Sheehy, because, among other things, it reduced opportunities for periodic legislative reappraisal, and possible repeal, of the benefit awards. See supra notes 31-39, 42, and accompanying text. Perhaps for these reasons, the court in Sheehy itself downplayed its reliance on the state's payment of increased benefits out of general treasury funds, deeming that fact "not conclusive." Sheehy, 864 P.2d at 768.

95. See Ragsdale, 895 P.2d at 1351; see also 895 P.2d at 1358 (Gillette, J., dissenting) ("That Oregon payments constitute] a partial refund of state taxes" is "demonstrated ineluctably by the fact that the increased... retirement benefits are not payable in any year in which ... retirement benefits are exempt from Oregon personal income taxation.").

96. The West Lynn Creamery case is discussed supra section I.C.

97. West Lynn Creamery, Inc. v. Healy, 512 U.S. 186, 201 (1994).

98. 895 P.2d at 1354.

99. See 895 P.2d at 1353 n.11. 
precisely because - just as in Ragsdale - the new obligation and new payment right were created simultaneously as part of an integrated legislative package. ${ }^{100}$ In addition, West Lynn Creamery provided ammunition for an a fortiori argument of unconstitutionality in Ragsdale because Oregon's payments were made - as true "rebates" are - back into the hands of the very class of persons on whom the new tax liability was imposed.101

Despite the preceding criticism of Ragsdale, there is something to be said for the result the majority reached in that case. Most important, the emphasis in Davis itself on the distinction between government-supplied payments, which are subject to federal income tax, and government-supplied tax exemptions, which are not, supports the result in Ragsdale - although it also suggests that the court erred in Sheehy. ${ }^{102}$ There also may be force in the argument that, because states can increase retirement benefits in general, they should be able to raise benefits contemporaneously with the enactment of a new tax. Again, however, this argument suggests that Sheehy is misbegotten. ${ }^{103}$ So which court got it wrong the court in Ragsdale or the court in Sheehy? We shall return to this question after we have developed in detail our general methodology for assessing linkage cases.

\section{UNIFORMITY AND EQUALITY}

We have thus far considered the question of suspect linkage between the imposition of a tax and the payment of governmental funds in the context of federal constitutional restraints on state taxing power. In West Lynn Creamery, the earmarking of revenues from a nondiscriminatory tax for a group of in-state beneficiaries led the Court to characterize the simultaneously enacted taxing and spending measures as an integrated scheme that violated the Commerce Clause. Similarly, in Sheehy, the repeal of a tax exemption that the state had granted for state - but not federal - retirement income, coupled with an increase in retirement benefits for

100. See 512 U.S. at 200 ; supra notes $26-30$ and accompanying text.

101. See supra notes 81-86 and accompanying text.

102. See supra notes $64-65$ and accompanying text (discussing Court's reliance on this distinction in Davis).

103. Not surprisingly, Judge Weber made precisely this argument. See Sheehy v. Public Employees Retirement Div., 864 P.2d 762, 774 (Mont. 1993) (Weber, J., specially concurring and dissenting) ("If the same adjustment payment provided in the Act were provided in another act in some future year, and denominated a cost of living, no one would even raise the discrimination argument. I do not find a basis to condemn the adjustment merely because it is included with the tax."). 
state retirees, led the court to find a discriminatory "rebate" that violated the intergovernmental tax immunity doctrine. In Ragsdale, on the other hand, the court was unwilling to condemn under the intergovernmental immunity doctrine a tax and spending package that effectively relieved state retirees from the burdens borne by federal retirees under the state income tax.

Analogous questions of suspect linkage between taxing and spending measures arise under state constitutional provisions. In particular, when the state provides tax reductions or abatements to a narrow group of taxpayers, the question arises as to how a court should characterize such "payments." Should the court view them as integrally related to the underlying taxing scheme and therefore violative of state constitutional provisions requiring uniformity and equality in taxation?104 Or should the court instead treat them as independent governmental expenditures, which are not subject to uniformity and equality restraints? Courts addressing such questions raised by state constitutional restraints have responded with discordant answers.

In Westvaco Corp. v. South Carolina Department of Revenue, ${ }^{105}$ the South Carolina Supreme Court considered the constitutionality of a credit against property taxes funded with the proceeds of a local option sales tax. The property tax credit was calculated as a fixed, single proportion of the fair market value of the property, regardless of its classification. The property taxes for which the credit was granted, however, followed the constitutional mandate that varying classifications of property be taxed according to defined percentages of fair market value - namely, $10.5 \%$ for industrial property, $6 \%$ for commercial property, and $4 \%$ for owner-occupied residential property. As a consequence, the property tax credit effectively reconfigured the relative tax burden borne by property according to the state's constitutionally imposed classification scheme and did so in a way that disfavored industrial property owners. ${ }^{106}$

104. See generally 1 Jerome R. Hellerstein \& Walter Hellerstein, State TAXATION II 2.01 (2d ed. 1993).

105. 467 S.E.2d 739 (S.C. 1995) (per curiam). In the interest of full disclosure, it should be noted that Walter Hellerstein represented Westvaco Corporation in the Westvaco case. The views expressed here, however, are his own (and those of Professor Coenen) and do not necessarily represent those of Westvaco Corporation.

106. The South Carolina Constitution explicitly provides for the relative share of the property tax burden that is to be bome by different classes of property. It does so by prescribing specified percentages of the property's fair market value that is to be placed on the tax rolls for assessment purposes. In particular, as noted in the text, the South Carolina Constitution provides that, for assessment purposes, $10.5 \%$ of the fair market value of indus- 
The court in Westvaco confronted essentially the same issue presented in West Lynn Creamery, Sheehy, and Ragsdale: whether the sales-tax-funded property tax credit and the property tax itself should be viewed as an integrated whole. The industrial-propertyowning taxpayer, not surprisingly, claimed that the inexorable effect of the credit was to rearrange the relative tax burdens borne by various classes of property in violation of the constitutionally prescribed tax-burden-sharing relationships. The state, in contrast, argued that the court should not consider the joint operation of the tax and the credit, but instead should uphold the scheme because the property tax, standing alone, conformed to the constitutional mandate. In the end, the court agreed with the state on the ground that the credit was properly viewed as a separate spending measure.

In reaching this conclusion, the court reasoned that "the plain language" of the uniformity and equality provision of the South Carolina Constitution "does not impose uniformity on the distribution of taxes."107 Rather, uniformity is required only "in the assessment of all property," 108 so that, in the court's view, uniformity is obtained "when property taxes are levied equally within the county."109 The local option sales tax credit scheme, on the other hand, "has not altered the levying of property taxes nor the assessment of property." 110 Instead, the court concluded, "the scheme merely levies a sales tax and distributes the sales tax in the form of a property tax credit."111

The Westvaco court's conclusion is defensible only if one accepts the analytical premise that one should consider the "distribution"

trial property, $6 \%$ of the fair market value of commercial property, and $4 \%$ of the fair market value of owner-occupied residential property are to be placed on the tax rolls. See S.C. CoNsT. art. X, \& 1 (amended 1977). The relationship between these assessment ratios - 10.5 to 6 to 4 - determines the relative tax burden that each class of property will bear. For example, if three parcels of industrial, commercial, and owner-occupied residential property were each worth $\$ 100,000$, they would be placed on the tax rolls at $\$ 10,500, \$ 6,000$, and $\$ 4,000$ respectively and, if the tax rate were $1 \%$, would bear taxes of $\$ 105, \$ 60$, and $\$ 40$ respectively.

The property tax credit altered the relative property tax burden bome by each class of property. For example, if $\$ 100$ of local option sales tax revenues were available to reduce property taxes and if the taxing district's property consisted solely of the three $\$ 100,000$ parcels of industrial, commercial, and owner-occupied residential property described above, each parcel would receive a credit of $\$ 33.33$. As a consequence, instead of bearing respective property taxes of $\$ 105, \$ 60$, and $\$ 40$, in the constitutionally prescribed ratio of 10.5 to 6 to 4 , the parcels would bear respective property taxes of $\$ 71.33, \$ 26.67$ and $\$ 6.67$, in a ratio of 10.7 to 4 to 1 .

107. Westvaco, 467 S.E.2d at 741.

108. 467 S.E.2d at 741.

109. 467 S.E.2d at 741.

110. 467 S.E.2d at 741.

111. 467 S.E.2d at 741. 
of the local sales tax revenues in the form of a property tax credit independently of the property taxes that the credit reduced. The court, however, never adequately explained why it should not have viewed the two measures together for purposes of constitutional analysis. As to the "plain language" argument that the constitution imposed no textual limitation on the "distribution" of taxes but only on the "assessment of property," the court's position is undermined by the fact that there never was any "distribution" of taxes at all. Taxpayers simply received a property tax bill reduced by the amount of the credit.

More fundamentally, the court never grappled with - or even acknowledged - the practical effect of the tax credit, which reconfigured real-world property tax bills no less than would have an outright constitution-defying alteration in the relative assessment ratios of all property in the state. 112

Other courts faced with state constitutional challenges have displayed more sensitivity to these practical-effect concerns, taking an approach strikingly different from Westvaco. In State ex rel. La Follette v. Torphy, ${ }^{113}$ for example, the Wisconsin Supreme Court considered the constitutionality of property tax credits provided to offset increased property tax assessments attributable to building improvements. The credits - which were funded out of the state's general treasury - were limited to owners of particular types of residential property that did not exceed a specified market value..$^{114}$ The state official charged with administering the credit scheme challenged its constitutionality on the ground that it violated Wisconsin's uniformity clause because it resulted in the imposition of unequal tax burdens on taxpayers who owned buildings of equal

112. The assessment ratio is the percentage of fair market value at which property is placed on the tax rolls. As noted above, see supra note 106, the South Carolina Constitution explicitly prescribes these ratios for different classes of property.

113. 270 N.W.2d 187 (Wis. 1978).

114. See 270 N.W.2d at 188 . It is worth noting that property taxes are imposed by local taxing jurisdictions. Consequently, the "credit" came in the form of an actual payment by the state - or a reduction in the taxpayer's state tax liability - rather than merely a reduction in the taxpayer's local property tax liability. For this reason Torphy seemed to present an even less appealing case for finding linkage than Westvaco. Although we might have characterized the payments involved in Torphy as "subsidies" equal to the taxpayer's local property tax liability, we have chosen to follow the state legislature's and court's characterization of the payments as "credits." As the court described the scheme:

The law provides tax credits, within prescribed limitations, to certain property owners for building and garage improvements which result in increased property tax assessments. The statutes set forth the method of calculating the tax credit. The tax credit, thus computed, is paid to the owner of the real estate by the state from the general revenue fund.

270 N.W.2d at 188. 
value. The state attorney general defended the credit, arguing that the uniformity clause was inapplicable because the credit was not part of a direct tax on real estate to which the uniformity clause applied but rather was an independent distribution of tax proceeds. He contended that "since each owner first pays the full property tax assessed and only later receives a credit from the state's general revenues, the tax burden of this property owner is not affected."115

The court, however, rejected this argument, holding that the property tax credit resulted in a violation of state uniformity strictures. The court reasoned that "[i]t is the effect of the statute, not the form, which determines whether it is a tax statute subject to the uniformity clause."116 Although the statute provided for payment of the tax credit from general revenues, "it is in substance a tax statute because it has the effect of changing the individual tax burden by granting a partial exemption."117 The fact that a credit was paid to some taxpayers and not to others led "to the indisputable conclusion that taxpayers owning equally valuable property will ultimately be paying disproportionate amounts of real estate taxes,"118 and "[t] $t]$ his is not uniformity." 119

The contrast between Westvaco and Torphy is striking. Indeed, it seems clear that Westvaco would have come out differently had it been decided by the Wisconsin court and that Torphy would have come out differently had it been decided by the South Carolina court. The Wisconsin court presumably would have reasoned in Westvaco that the property tax credit, even though derived from sales tax proceeds, "is in substance a tax statute because it has the effect of changing the individual tax burden."120 Accordingly, the credit would have failed to comport with the requirements of South Carolina's constitutionally based property tax classification scheme. In contrast, the South Carolina court presumably would have reasoned in Torphy that the provision of a property tax credit from general revenue sources does no violence to the constitutional requirement of uniformity in taxation because the constitution "does not impose uniformity on the distribution of taxes." 121 The

115. 270 N.W.2d at $190-91$.

116. 270 N.W.2d at 192.

117. 270 N.W.2d at 192.

118. 270 N.W.2d at $192-93$.

119. 270 N.W.2d at 193.

120. Torphy, 270 N.W.2d at 192; see also supra text accompanying note 111.

121. Westvaco Corp. v. South Carolina Dept. of Revenue, 476 S.E.2d 739, 741 (S.C. 1995) (per curiam); see also supra text accompanying note 107. 
court would have tracked the analysis of the Wisconsin attorney general that "since each owner first pays the full property tax assessed and only later receives a credit from the state's general revenues, the tax burden of this property owner is not affected"122 - at least not in a constitutional sense.

The doctrinal problem pointed out by Westvaco and Torphy is not merely theoretical. In fact, a wide variety of state uniformity and equality cases raise the same linkage issue and reflect the same doctrinal dichotomy revealed by the South Carolina and Wisconsin cases. ${ }^{123}$ The most troublesome aspect of these decisions is not that they came out differently. Inconsistent precedents are commonplace in the law, and they simply may reflect the reality that different courts possess different (but reasonable) views as to the proper resolution of particular issues. What is troublesome about these cases is that they offer almost no clue as to why they came out differently. The courts have failed to indicate what it is that leads them to consider or not consider taxing and spending measures as linked for purposes of constitutional analysis.

\section{Towards a More Systematic Approach TO THE "LINKAGE" ISSUE}

In this final section, we undertake to fill the gaps in judicial analyses of tax discrimination issues under the dormant Commerce Clause, the intergovernmental tax immunity doctrine, and state uniformity and equality provisions. By articulating a three-step methodology built around specific criteria, we seek to offer guidance on whether taxing and spending measures should be analyzed together for purposes of both federal and state constitutional constraints on discriminatory state taxation. Before turning to our own methodology, however, we consider and reject two other possible approaches.

122. Torphy, 270 N.W.2d at $190-91$.

123. Compare Baker v. Matheson, 607 P.2d 233 (Utah 1979) (holding that a refund of property taxes to renters and homeowners from state's general fund does not violate state's uniformity clause because the refund is not remission of property taxes but merely appropriation subject to relaxed constitutional scrutiny) and State ex rel. Harvey v. Morgan, 139 N.W.2d 585 (Wis. 1966) (holding that credit provided to property owners from state's general fund did not violate uniformity and equality requirements because credit was tied to individual's characteristics, not those of property, and was credit against income rather than property taxes) with State v. Armstrong, 53 P. 981,983 (Utah 1898) (holding that statute creating abatement of taxes for indigent and infirm taxpayers violates constitutional requirement of uniformity, even though abatement relieves taxpayer of tax burden only after it has been levied, because legislature may not "do indirectly that which could not be done directly"). 


\section{A. Other Possible Approaches}

\section{Substance and Form}

The root of the problem in the linkage cases lies in the tension they display between the rule of substance and the rule of form. Decisions that view taxing and spending measures together and invalidate them on the ground that they collectively violate some constitutional norm invariably look through the "form" of the separate, individually valid measures to their combined, illicit "substance."124 Similarly, decisions that view taxing and spending measures individually and sustain them because of their independent validity invariably rely on the form in which the enactments are cast and do not accord legal significance to their combined net effect. ${ }^{225}$

Identifying the core difficulty with the linkage cases as one of substance versus form might appear to offer a ready solution to the problems that they raise. After all, it is well established, especially in tax cases, that substance and not form should govern legal analysis. ${ }^{126}$ The United States Supreme Court in adjudicating the constitutionality of state tax cases has observed that "we must look through form and behind labels to substance,"127 and it has explicitly embraced an approach that "consider[s] not the formal language of the tax statute but rather its practical effect."128 Thus the Court's contemporary state tax jurisprudence is grounded in "economic realities,",129 wedded to "pragmatism,"130 disdainful of "formalism,"131 and contemptuous of "magic words or labels."132 From

124. See, e.g., supra notes 116-17 and accompanying text (discussing the Torphy case); see also Ragsdale v. Department of Revenue, 895 P.2d 1348, 1358 (Or.) (Gillette, J., dissenting) ("Substance counts; labels do not."), cert. denied, 116 S. Ct. 569 (1995).

125. See, e.g., supra notes $81-91$ and accompanying text (discussing Ragsdale decision).

126. See, e.g., Frank Lyon Co. v. United States, 435 U.S. 561, $572-73$ (1978) ("In applying this doctrine of substance over form, the Court has looked to the objective economic realities of a transaction rather than to the particular form the parties employed."); Helvering v. F. \& R. Lazarus \& Co., 308 U.S. 252, 255 (1939) ("In the field of taxation, administrators of the laws, and the courts, are concemed with substance and realities, and formal written documents are not rigidly binding.").

127. City of Detroit v. Murray Corp. of Am., 355 U.S. 489, 492 (1958).

128. Oklahoma Tax Commn. v. Jefferson Lines, Inc., 514 U.S. 175, 183 (1995) (internal quotation marks omitted) (quoting Complete Auto Transit, Inc. v. Brady, 430 U.S. 274, 279 (1977)); see also Nippert v. City of Richmond, 327 U.S. 416, 431 (1946) ("Not the tax in a vacuum of words, but its practical consequences ... are our concern.").

129. Complete Auto Transit, 430 U.S. at 279.

130. Quill Corp. v. North Dakota, 504 U.S. 298, 310 (1992).

131. Trinova Corp. v. Michigan Dept. of Treasury, 498 U.S. 358, 373 (1991).

132. Quilh, 504 U.S. at 310 (internal quotation marks omitted) (quoting Railway Express Agency, Inc. v. Virginia, 358 U.S. 434, 441 (1959)). 
these many authorities, it might seem to follow easily that linkage cases should simply turn on whether the challenged payment in substance replicates discriminatory tax relief.

The difficulty with this "solution" to the linkage problem, however, is twofold. First, even if one eschews form for substance, it is not always clear what constitutes form and what constitutes substance. Is it merely a matter of form, for example, that a taxing measure and a spending measure were embodied in separate pieces of legislation, took different routes through the legislative process, and were enacted in separate legislative sessions? If so, is there a point at which such "formal" differences between taxing and spending measures rise to the level of substance? If Alaska imposes an income tax on residents and nonresidents, can it increase its Permanent Fund dividend paid to residents without violating the Privileges and Immunities Clause? Or will the dividend result in a constitutional violation on the theory that Alaska has reduced residents' effective income tax liabilities and thereby "in substance" imposed a discriminatory income tax on nonresidents? ${ }^{133}$ Does the timing of the increase matter? Does the amount of the increase matter? Does it matter whether the dividend is a percentage of the resident's tax bill? Does it matter whether the increased dividend offsets in toto the tax bills of all (or most or many) state residents? In short, are these matters of substance or of form?

Second, despite the oft-uttered injunction that substance should prevail over form, courts - including the Supreme Court - frequently have concluded that form can and should play a key role in resolving state tax controversies. ${ }^{134}$ In Oklahoma Tax Commission v. Jefferson Lines, Inc., ${ }^{135}$ for example, the Court sustained against a challenge under the Commerce Clause a "sales tax" measured by the unapportioned gross proceeds from interstate transportation; at the same time the Court reaffirmed an earlier decision invalidating an economically identical "gross receipts tax" measured by the

133. The example in the text borrows from the recent suggestion of Jay Hammond, Alaska's governor from 1975 through 1982, that the state impose an income tax on state residents and nonresidents, accompanied by an increase in the Permanent Fund dividend to state residents, in order to neutralize the effect of the income tax on Alaskans. See Former Governor Calls for Nation's Highest Income Tax, 10 STATE TAX Notes 1852 (1996).

134. See, e.g., Mueller v. Allen, 463 U.S. 388, 397 n.6 (1983) (stating that in cases involving tax relief said impermissibly to aid religious schools, "the form of the [State's assistance ... must be examined] for the light it casts on the substance'" (quoting Lemon v. Kurtzman, 403 U.S. 602, 614 (1971)), and that "[t]he fact that the Minnesota plan embodies a 'genuine tax deduction' is thus of some relevance" even though "the economic consequences of the program in Nyquist and that in this case may be difficult to distinguish").

135. 514 U.S. 175 (1995). 
unapportioned gross proceeds from interstate transportation. ${ }^{136}$ The Court's decision in Jefferson Lines rested squarely on formal differences between a "sales tax," which is imposed on the purchaser, and a "gross receipts tax," which is imposed on the seller. ${ }^{137}$ While recognizing a general hostility to "the adoption of purely formal distinctions," the Court nevertheless observed that "economic equivalence alone has ... not been (and should not be) the touchstone of Commerce Clause jurisprudence."138

Likewise, in Quill Corp. v. North Dakota, ${ }^{139}$ the Court adopted a "bright-line rule" that requires an out-of-state vendor to collect sales and use taxes only if the vendor is physically present in the taxing state. ${ }^{140}$ This test was admittedly formalistic, for it immunized even large, sophisticated mail-order sellers with millions of dollars of local sales from any obligation to collect the state's use tax, while imposing a collection obligation on small, Mom-and-Pop retailers that happened to send a salesman into the state. As the Court declared, however, "not all formalism is alike."141 While some formal distinctions may serve no valid constitutional purpose, the formalistic, bright-line rule approved in Quill "furthers the ends of the dormant Commerce Clause":142 It avoids burdens on interstate commerce "by the demarcation of a discrete realm of commercial activity that is free from interstate taxation,"143 and it "encourages settled expectations and, in doing so, fosters investment by businesses and individuals." 144

136. 514 U.S. at 189-90 (reaffirming Central Greyhound Lines, Inc. v. Mealey, 334 U.S. 653 (1948)).

137. 514 U.S. at 190. See generally Walter Hellerstein et al., Commerce Clause Restraints on State Taxation After Jefferson Lines, 51 TAX L. REv. 47 (1995).

138. Jefferson Lines, 514 U.S. at 196 n.7.

139. 504 U.S. 298 (1992).

140. 504 U.S. at 316.

141. 504 U.S. at 314.

142. 504 U.S. at 314.

143. 504 U.S. at 315.

144. 504 U.S. at 316. In a similar vein, in Oklahoma Tax Commission v. Chickasaw Nation, 115 S. Ct. 2214, 2221 (1995), the Court was unwilling "to make 'economic reality' our guide" for determining the validity of state taxes on Indians. Instead, the Court endorsed a more formalistic approach to the issue under which the "legal incidence" of the tax determined whether it fell on Indians for constitutional purposes. The Court observed that "a 'legal incidence' test ... . 'provide[s] a reasonably bright-line standard which, from a tax administration perspective, responds to the need for substantial certainty as to the permissible scope of state taxation authority.'" $115 \mathrm{~S}$. Ct. at 2221 (alteration in original) (citation omitted). Legal incidence also has played a critical role in determining when state taxes that touch federal government operations run afoul of the intergovernmental tax immunity rule. See 2 Hellerstein \& Hellerstein, supra note 104, II 22.02[2]; LAurence H. Tribe, American Constitutional LaW $\S 8-30$ to -32 (2d ed. 1988). 
In sum, while superficially attractive, the notion that linkage issues should be resolved by letting substance govern form provides no easy solution to this set of problems. First, it fails to provide a workable test for distinguishing valid from invalid taxing and spending schemes, since the line between substance and form is ambiguous. Second, a mechanical subordination of form to function cannot be squared with a deeply rooted judicial respect for form that coexists - albeit uneasily - with courts' commitment to resolving these issues on the basis of substance. If we are to develop an approach to the linkage issue that not only improves upon what courts have been doing but also offers them an alternative that they will find acceptable, we cannot merely mouth the platitude that, in these matters, substance governs form.

\section{Motive-Based Analysis}

Another approach to linkage cases would call on courts to frame their inquiries in terms of legislative motive. In particular, courts might make linkage decisions turn upon the answer to a single question: Did the state adopt its discriminatory spending program with the specific intent of offsetting or mitigating obligations to pay a state tax? The majority in Sheehy appeared to adopt this sort of purposive approach. ${ }^{145} \mathrm{We}$, however, would reject it for three separate reasons.

First, any such approach will suffer from the same maladies that mark all motive-driven rules - problems of discovering and weighing evidence of motive, of characterizing motives, and of dealing with the multiple motives that often together trigger government action. ${ }^{146}$ These problems, moreover, are particularly acute in this

145. See supra notes $73-80$ and accompanying text.

146. The seminal treatments of this subject include John Hart Ely, Legislative and Administrative Motivation in Constitutional Law, 79 YALE L.J. 1205 (1970), and Paul Brest, Palmer v. Thompson: An Approach to the Problem of Unconstitutional Legislative Motive, 1971 Sur. Cr. Rev. 95. See also Symposium, Legislative Motivation, 15 San DIEgo L. Rev. 925 (1978). For useful commentaries on this question by the Supreme Court, see, e.g., Pacific Gas \& Elec. Co. v. State Energy Resources Cons. \& Dev. Commn. 461 U.S. 190, 216 (1983) ("What motivates one legislator to vote for a statute is not necessarily what motivates scores of others to enact it."); Kassel v. Consolidated Freightways Corp., 450 U.S. 662, 702-03 (1981) (Rehnquist, J., dissenting) (citing flaws in assuming "that individual legislators are motivated by one discernible 'actual' purpose" and noting that "different legislators may vote for a single piece of legislation for widely different reasons"); United States v. O'Brien, 391 U.S. 367, 383-84 (1968) (noting that purpose-driven inquiries "are a hazardous matter," in part, because results may tum on "what fewer than a handful of Congressmen said"). See also Village of Arlington Heights v. Metropolitan Hous. Dev. Corp., 429 U.S. 252, 265-66, 268 n.18 (1977) (observing that "judicial inquiries into legislative or executive motivation represent a substantial intrusion into the workings of other branches of government"). See generally Henneford v. Silas Mason Co., 300 U.S. 577, 586 (1937) (noting that "motives alone will seldom, if ever, invalidate a tax that apart from its motives would be recognized as lawful"). 
setting because spending decisions are almost never made by a single administrator or a small body of agency officials whose motives may be discrete and identifiable. Instead, spending decisions typically are made, often after elaborate political posturing, by the state legislature itself. ${ }^{147}$

Second, we doubt that a tax-reducing motive by itself, even if discoverable, always should establish linkage for purposes of constitutional tax discrimination rules. The court in Ragsdale, for example, explicitly rejected this position, ${ }^{148}$ and there is reason to believe it was on firm ground in doing so. In particular, the United States Supreme Court has built important constitutional doctrines around the notion that in-state taxpayers should be able to reap where they have sown by redirecting to favored state residents the proceeds of state tax collections. ${ }^{149}$ It may well follow that the state should be able to channel benefits to groups of its own residents it could not favor with discriminatory taxes, even if the state is responding in part to demands for tax relief.

Third and most important, we would eschew a purpose-based test because we believe a more objective, more workable, and more just approach exists. The remainder of this article develops that approach. We turn now to detailing its structure and implications.

147. We recognize, of course, that the Supreme Court has required inquiries into governmental motives in a variety of settings, see generally TRIBE, supra note 144, §5-3, at $303 \mathrm{n} .10$ (collecting illustrations), and that it has observed in particular that, for purposes of the dormant Commerce Clause, a fatal finding of economic protectionism may rest "on proof either of discriminatory effect ... or of discriminatory purpose," Minnesota v. Clover Leaf Creamery Co., 449 U.S. 456, 471 n.15 (1981). The inquiry into whether a particular law is discriminatory because of its underlying purpose, however, must be distinguished from the inquiry whether the legislature's purpose requires viewing ostensibly separated taxing and spending measures as inextricably connected for purposes of discrimination analysis.

148. See Ragsdale v. Department of Revenue, 895 P.2d 1348, 1356 (Or.) ("The state is entitled to raise the level of taxable compensation of its employees, for whatever reason, including to compensate them for a change in the tax laws that results in a decreased level of net after-tax income"), cert. denied, 116 S. Ct. 569 (1995).

149. See, e.g., United Bldg. \& Constr. Trades Council v. Mayor of Camden, 465 U.S. 208, 221 (1984) (noting that the "fact that [the city] is expending its own funds ... is certainly a factor - perhaps the crucial factor - to be considered in evaluating [the constitutionality of discrimination against nonresidents]"); White v. Massachusetts Council of Constr. Employers, Inc., 460 U.S. 204, 214 (1983) (upholding municipal hiring preference on projects for which "the city expended only its own funds"); Reeves, Inc. v. Stake, 447 U.S. 429, 442 (1980) (defending market-participant exception to dormant Commerce Clause in part on the ground that state may channel state benefits to residents of the state supplying them). 


\section{B. The Criteria of Linkage}

\section{Basic Principles}

Life and law are too complex to permit identification of one simple test by which courts can assess the existence (or nonexistence) of a cognizable linkage between taxing and spending measures. A more fruitful approach to the problem calls for the recognition that there are a number of criteria that ought to inform a court's determination as to whether it should treat a taxing provision and a purportedly independent spending measure as an integrated whole. In our view, these criteria have in fact influenced courts when they have determined that taxing and spending measures should be treated as linked, even though the courts often have failed to articulate that they are using these criteria in making that determination. By systematically identifying the criteria that ought to inform judicial decisionmaking in this area and by detailing how those criteria properly interact, we seek to provide a framework for a more reasoned approach to linkage issues than is discoverable in the existing case law.

While the remainder of this article develops these matters in detail, we offer now the essential guideposts of analysis. First, in our view, the results in linkage cases typically should hinge on the operation of five identifiable factors. We refer to these factors as (a) internalization, (b) simultaneity, (c) scope, (d) correlation, and (e) policy responsiveness. In our view, the first four of these factors differ from the fifth in that they are equally applicable in all linkage cases and, at least in their strongest manifestations, are subject to ready and objective identification. We shall explain in short order what each of these five key terms denotes.

Second, our inspection of and reflection on this body of cases convinces us that courts ought to extract - and, as a practical matter, already have extracted to a large extent - from these criteria three key principles. These principles - which we shall elaborate on in due course - may be summarized as follows:

Principle \#1 (the virtually per se internalization rule): In the area of tax credits and exemptions, whenever the state legislature internalizes an alleged "payment" to a particular tax - in the sense that the credit directly serves to reduce that very tax - $a$ "virtually per se rule"150 operates to establish linkage. The determinative linking factor in $\mathrm{New}$

150. We borrow the term "virtually per se rule" from City of Philadelphia v. New Jersey, 437 U.S. 617, 624 (1978). We recognize, of course, that the term was used in a very different context in that case, but we employ it here because we think it best captures the nature of the very strong principle we mean to describe. 
Energy, for example, lay in the state's decision to reduce the fuel tax obligations of members of the favored group - sellers of locally produced ethanol - by granting them credit against that very tax.151

Principle \#2 (the twin-indicia rule of thumb): In the area of outright payments, the internalization rule cannot operate because, as we shall see, internalization cannot be present by definition. ${ }^{152}$ Likewise, internalization is absent in some cases that involve tax credits and exemptions. ${ }^{153}$ In many "noninternalization" cases, however, linkage is present, although it is not always easy to decide when. We believe, however, that application of a rule of thumb will greatly aid the process of decision. This rule stipulates that a strong presumption of linkage exists when two of our three "objective" linkage factors other than internalization - that is, simultaneity, correlation, and scope are present in a strong sense. We shall explain in short order what we mean by "a strong sense," particularly with respect to correlation, which constitutes the least objectifiable of these three criteria.

Principle \#3 (the five-factor mode of analysis): In all other cases (that is, in all cases not covered by either Principle \#1 or Principle \#2), courts should consider all five linking factors in deciding whether to treat the taxing measure and the spending measure as parts of an inseparable whole. This mode of analysis is not as open ended and manipulable as this shorthand description of the principle might suggest. Rather, as we shall soon see, existing authorities and articulable principles will constrain judicial excesses as courts confront this most complicated set of linkage cases.

A good place to start in assessing and applying this methodology is with the easiest case. After looking at that case - and developing in that context the essential features of our five key linkage factors - we turn to cases that present more difficult and interesting constitutional linkage issues.

\section{The Paradigmatic Case}

If there is a paradigmatic case of constitutionally linked taxing and spending measures, it is the case of the tax credit or exemption enacted along with and exactly offsetting the underlying tax in such a way as to disfavor all and only members of a constitutionally protected group..$^{154}$ No one would seriously defend, for example, a

151. For a discussion of New Energy, see supra notes 16-18 and accompanying text.

152. See infra notes $223-24$ and accompanying text.

153. See infra notes $191-98$ and accompanying text.

154. One might question whether a tax exemption should be viewed as a "spending" measure at all. One could say that the imposition of a tax along with an exemption simply amounts to the enactment of a tax on the class of taxpayers not qualifying for the exemption. Accordingly, one could argue that the tax should be struck down as discriminatory without further inquiry as to whether a spending measure is linked to a taxing measure, assuming the class of taxpayers upon which the tax has been imposed has a right not to be subjected to discriminatory taxes. 
nondiscriminatory tax imposed on residents and nonresidents alike, but coupled with a credit or exemption, provided only to residents, that exactly neutralizes the tax. Even though the tax would pass muster standing alone, ${ }^{155}$ and even though a state spending measure limited solely to favored residents presumably would pass muster too, ${ }^{156}$ courts would invalidate the tax-and-credit or tax-andexemption scheme described above. They would reason that such a program in substance amounts to a tax imposed solely on nonresidents in violation of the Privileges and Immunities Clause. ${ }^{157}$

How do we know that a state tax and a credit or exemption of the type described above are invidiously linked? The answer is that they display all of the key indicia of linkage that justify treating them as a single measure. To use our terms, the challenged scheme involves internalization, simultaneity, scope, correlation, and policy responsiveness. Indeed, each of these key linkage factors is present in a strong and unmistakable sense.

a. Internalization. In our paradigmatic case, strong internalization is present because the credit or exemption defended as an independent payment measure reduces the challenged tax qua tax. Our paradigmatic case does not involve any outright payment made to the taxpayer. It also does not involve a credit against a tax based on payment of some other tax - as would exist, for example, if the state afforded a class of persons a credit against state real property taxes for state income tax payments made within the prior year. Instead, the alleged payment, made by way of the credit or exemption, is internalized in the pure sense that the legislature itself has

While we do not necessarily disagree with this suggestion, we nevertheless have included exemptions along with credits in this discussion for four reasons. First, some would argue that tax exemptions should in fact be viewed as a form of govermmental expenditures. See, e.g., Stanley S. SuRrey \& Paul R. McDaniel, Tax Expenditures 212-13 (1985). Second, tax exemptions seem a proper subject of discussion because their economic effect is so clearly comparable to government actions that more clearly involve governmental "spending" - e.g., tax credits, tax rebates, and subsidies. Third, some of the relevant cases involve both credits and exemptions without distinguishing between the two. See, e.g., Maryland v. Louisiana, 451 U.S. 725 (1981), discussed infra at text accompanying notes 192-98. Finally, the benefits of including exemptions in the discussion appear to us to outweigh the drawbacks. Specifically, at the risk of making our discussion slightly overinclusive - and, as noted above, there are those who would argue that we are doing no such thing - we are able to draw on the insights of cases involving taxes and exemptions as well those involving taxes and measures that are more invariably viewed as involving governmental spending.

155. See supra note 1 and accompanying text.

156. Zobel v. Williams, 457 U.S. 55, 65, 67-68 (1982) (Brennan, J., concurring) ("[A] state may make residence within its boundaries more attractive by offering direct benefits to its citizens in the form of ... direct distributions of its munificence.").

157. See, e.g., Austin v. New Hampshire, 420 U.S. 656 (1975) (invalidating under Privileges and Immunities Clause facially neutral tax on the income of interstate commuters that effectively fell exclusively on nonresidents due to exemptions from the tax). 
structured that payment as a method of directly reducing the obligation to pay the single, particular tax against which the credit or exemption operates.

Most tax credits and exemptions work in this way, and in all such cases strong internalization is present. When, in contrast, the state credits one tax against another - as in our income-tax/property-tax hypothetical - we would say that only weak internalization exists. 158 And when the state does not purport to grant tax relief at all, but instead makes outright payments, we would say, except in cases involving true tax rebates, ${ }^{159}$ that there is no internalization at all.

b. Simultaneity. Simultaneity also is present in our paradigmatic case, and it serves three linkage functions. First, simultaneity - like internalization - gives rise to a connection between the tax and spending measures simply as a matter of form. As we have seen, though considerations of form have their limits, they can and do count for something in constitutional tax cases. ${ }^{160}$ Second, simultaneity is strongly suggestive of a legislative purpose to have the spending program offset the tax in a manner functionally akin to the sort of credit or exemption that gives rise to internalization. We previously have explained why proof of such a motive should not be all important for purposes of linkage analysis; ${ }^{161}$ to make that observation, however, is not to say that legislative motives when objectively evidenced - should count for nothing at all. Third, simultaneity may well distort political processes in a way that raises particular risks of factional overreaching. The majority in West Lynn Creamery focused on this point, ${ }^{162}$ and we believe it was on solid ground in doing so. ${ }^{163}$

158. An illustrative case that involves weak internalization is Maryland v. Louisiana, 451 U.S. 725 (1981), which we discuss infra at notes $192-98$ and accompanying text.

159. See infra notes $223-27$ and accompanying text.

160. See supra notes $124-44$ and accompanying text.

161. See supra notes $145-49$ and accompanying text.

162. See supra note 44 and accompanying text.

163. Two recent cases in which simultaneity appeared to play a key role are Zenith Kremer Waste Systems, Inc. v. Western Lake Superior Sanitary District, 558 N.W.2d 288 (Minn. Ct. App. 1997), review granted, 1997 Minn. LEXIS 267 (Minn. Mar. 27, 1997) and Sanifill, Inc. v. Kandiyohi County, 559 N.W.2d 111 (Minn. Ct. App. 1997). In each case, a public waste-processing facility charged high tipping fees. When a major hauler of local waste announced plans to discontinue use of the facility and haul materials out of state, the public facility operator. (1) imposed a charge on all waste generated within the waste facility district; (2) directed that a portion of the resulting revenue be used to pay for the operation of the waste facility; and (3) reduced tipping fees. The consequence of these actions was that persons who hauled waste out of state continued to pay full tipping fees plus the new in-state waste charge, while persons who hauled waste to the local facility paid the new waste charge but also paid lower tipping fees attributable to that charge. In each case, the court found a 
Simultaneity, like internalization, is an objectively identifiable trait that should generally be readily recognizable by courts. Occasionally, however, judges will have to struggle with this factor, for literal simultaneity should not be required to bring the factor into play; substantial simultaneity - like substantial performance in the law of contracts ${ }^{164}$ - ought to suffice for this purpose. But in most cases simultaneity clearly is or is not present, particularly because in most cases that do involve simultaneity, the state will have adopted the challenged taxing and spending measures as part of the same legislative program. ${ }^{165}$ Such is the situation in our paradigmatic case.

c. Scope. A third linkage factor - what we call "scope" concerns the relationship between the class of taxpayers, the class of payment beneficiaries, and the class of persons protected by the operative constitutional rule. In our paradigmatic case, for example, the scope factor operates in its strongest form because the Privileges and Immunities Clause guards against discrimination between residents and nonresidents, ${ }^{166}$ and the tax exemption or credit afforded by the state covers all, but only, those state residents subject to the tax. Such a payment, in our nomenclature, is universal in scope.

The subject of scope, in its details, is marked by some complexity. Some spending measures are under-universal in scope. ${ }^{167}$

Commerce Clause violation because "the combination of the service fee and the tipping fee would be discriminatory in its effect." Sanifill, 559 N.W.2d at 116. Notably, the general waste charge and the tipping fee reduction were not adopted with literal simultaneity in Zenith/Kremer although (1) they had the same effective date, and (2) adoption of the charge came under consideration "[a]t the same time" the fee reduction was announced. Zenith/ Kremer, 558 N.W.2d at 290. Drawing on West Lynn Creamery, the court in Zenith/Kremer found a constitutional violation because "[h]aulers to out-of-state landfills pay the entire management fee, but do not receive the 'rebate' that haulers to the Facility receive through the Facility's reduced tipping fee." 558 N.W.2d at 291.

164. See generally E. Allan Farnsworth, CONTRACTs $\$ 8.12$ (2d ed. 1990) (discussing substantial performance as a means to avoid forfeiture).

165. See, e.g., West Lynn Creamery, Inc. v. Healy, 512 U.S. 186 (1994), discussed supra notes $21-41$ and accompanying text.

166. See, e.g., Toomer v. Witsell, 334 U.S. 385 (1948).

167. In our paradigmatic case, for example, there was a perfect universality of scope because relief from the tax was afforded only to the class that was forbidden by the Privileges and Immunities Clause from being favored - i.e., only to state residents - and relief was afforded to all members of that class - i.e., to all state residents. Many tax credits and exemptions (and other forms of spending), however, are under-universal with respect to scope. For example, the credit in New Energy, discussed supra notes 16-20 and accompanying text, was under-universal because all in-state sellers and producers of vehicle fuel other than gasohol continued to bear the brunt of the tax. In our view, under-universality of scope should cut against a finding of linkage. See infra note 170. 
Others are over-universal. ${ }^{168}$ Spending measures can be overuniversal in different respects. 169 And some spending measures are both under- and over-universal, and over-universal in different ways. ${ }^{170}$ These varying forms of scope will matter in deciding actual cases and will be touched upon further in our later discussions.

d. Correlation. Correlation differs from internalization, simultaneity, and scope because - as we use the term - it embraces several different forms of connectedness between taxing and spending measures. In particular, a spending measure may link up with a taxing measure by way of (1) durational correlation, which is present when the payment measure is to operate only for as long as the challenged tax; (2) computational correlation, which is present when tax obligations and subsidy payments bear a significant mathematical relationship, as when both are computed as a stated percentage of gross receipts; and (3) source-based correlation, which is

168. The New Energy case reveals a type of overuniversality that we might - because it is a Commerce Clause case - call "interstate overuniversality." This label fits because New Energy involved a credit afforded both to members of the not-to-be-favored class of dealers in intrastate fuel and - because of the statute's reciprocity provision - to some members of the protected class of dealers in interstate fuel. It can be argued that this sort of overuniversality strengthens the case for linkage on the ground that if $X$ equals linkage (with $X$ constituting universal coverage as we have defined it), then a fortiori so should $X$ plus $Y$. On the other hand, it may be that this form of overinclusiveness weakens the case for linkage because it reduces the extent of discrimination and lessens the resemblance of the overall taxing-and-spending scheme to a protective tariff. See Hellerstein \& Coenen, supra note 15, at 846-48. Our sense is that interstate overuniversal scope probably should be treated as involving substantial universality for purposes of the presumption established by our Principle $\$ 2$, although there is room for disagreement on this point. At the least, however, we believe that interstate overuniversality should not weigh against linkage when, as in New Energy itself, the interstate overuniversality results from a reciprocity provision. Such provisions, after all, simply put a group of states in the same discriminatory posture that a single state cannot occupy.

169. Just as a spending measure may be marked by interstate overuniversality, see supra note 168 , it may be marked as well by intrastate overuniversality. Assume, for example, that the fuel tax involved in New Energy was enacted simultaneously with an outright subsidy program for sellers of all locally produced corn products, including locally produced ethanol (as well as sellers of products from subsidy-reciprocating states). The grant of the subsidy to sellers of locally produced com products other than ethanol - for example, locally produced corn meal or corn chowder - would establish the payment program's intrastate overuniversality vis-à-vis the motor fuel tax. One can argue that the scope factor serves less well to link this subsidy to the Ohio fuel tax than to link the actual credit involved in New Energy to that tax. After all, what does com chowder or com meal have to do with fuel and its taxation? On the other hand, intrastate overuniversality is problematic from a political-process perspective - and thus supportive of the case for linkage - because, at least if there is simultaneity, it multiplies the number of in-state interests prepared to push for enactment of a potentially overreaching tax. For this reason, we believe that intrastate overuniversality should at least count for more than interstate overuniversality in tying together taxing and spending measures.

170. Indeed, our hypothetical com products subsidy case involves underuniversality (because sellers of local fuel products other than ethanol remain taxed), interstate overuniversality (because of the reciprocity provision) and intrastate overuniversality (because the subsidy extends to such subjects as com chowder and com meal). 
present when the state sets aside some or all of the proceeds of the challenged tax itself to fund its payment program, or calculates total payments as a function of tax receipts.

When we apply each of these correlation criteria to our paradigmatic case, we see that it presents the very strongest form of correlation. There is durational correlation because any exemption or credit from a tax by definition can last only as long as does the tax. There is computational correlation because the credit or exemption offsets exactly, on a dollar-for-dollar basis, the tax bill the beneficiary otherwise would pay. And, at least in effect, there is sourcebased correlation too. If the state, for example, provided for rebates of the very payments favored taxpayers had made, sourcebased correlation would clearly exist. Should we not conclude a fortiori that source-based correlation exists when, instead of going through the gyrations of collecting and returning tax money, the state simply affords credits or exemptions from the challenged tax? We think so.

It bears emphasis that declaring the presence of strong correlation often will involve a greater exercise of discretionary judgment than finding internalization, simultaneity, or universality of scope. This is because the existence of correlation is not simply an "on-off" matter. Indeed, the very fact that there are multiple indicia of correlation, some or all of which may be present in a given case, reveals that finding correlation means choosing a place on a continuum. At the same time, in many cases it will be clear that a strong correlation exists. In particular, we believe that such correlation almost always marks the case when two of the three forms of correlation (that is, durational, computational, and source-based) are present.

e. Policy Responsiveness. The final linkage factor - what we call "policy responsiveness" - calls on courts to ask whether the challenged state program raises distinctive concerns in light of the policies that drive the particular tax discrimination doctrine at issue. In our paradigmatic case, for example, we believe that a distinctive and important policy concern, rooted in the Privileges and Immunities Clause, supports the argument for finding linkage.

The argument for finding linkage derives force from the Privileges and Immunities Clause's underlying purpose of weaving the nation together by directly "tying the fate" of out-of-state resi- 
dents to the state's treatment of its own residents. ${ }^{171}$ This policy concern is triggered whenever there is simultaneity and universality of scope. Simultaneity is significant because it is the contemporaneous enactment of the tax and one offsetting "payment" that permits the resident-favoring discrimination to take hold. Put another way, if the state were forced first to enact a neutral nondiscriminatory tax - and only later permitted to consider whether to adopt an exemption - the close tying of the fates of residents and nonresidents with respect to the tax suggests that the tax would not be enacted in the first place. Likewise, whenever there is perfect universality of scope the risk of oppression is heightened because not a single resident will be directly disadvantaged by the tax and thus stand ready to serve as a surrogate protector of nonresidents' interests. It follows that even if a state tax is narrow in its coverage - in that, for example, it applies only to members of a particular profession - an exemption that favors all residents subject to the tax creates a particularly grave danger of illicit overreaching. ${ }^{172}$ In our paradigmatic case, however, this concern about overreaching is triggered in an additional and particularly significant way.

Why? Because our hypothetical statute places a tax on all persons - not just some subclass of persons - and affords an offsetting credit or exemption to every single resident of the state. In such a case, the ordinary counterweight to enactment of an unworthy state spending program - namely, the natural opposition directed to it by voters who do not enjoy its benefits - cannot possibly operate because all voters in the state benefit from the spending program. In other words, the genuinely global reach of the spending component of the state's program in our paradigmatic case serves to ensure the total absence of surrogate representation by in-state residents of the interests of burdened outsiders. In these circumstances, the policy that supports the Privileges and Immunities Clause stands uniquely at risk. Thus, the factor we call "policy responsiveness" cuts in favor of finding linkage. ${ }^{173}$

$f$. Conclusion. This analysis of our paradigm introduces the factors that should drive linkage analysis in tax-discrimination cases.

171. See, e.g., Jokn HART ELY, Democracy AND Distrust 83 (1980) ("[B]y constitutionally tying the fate of outsiders to the fate of those possessing political power, the framers insured that their interests would be well looked after.").

172. See Ward v. Maryland, 79 U.S. (12 Wall.) 418 (1871) (invalidating differing license fees imposed on resident and nonresident sellers of goods).

173. See Travis v. Yale \& Towne Mfg. Co., 252 U.S. 60, 80-81 (1920) (distinguishing tax that presents "a case of occasional or accidental inequality" from "a general rule, operating to the disadvantage of all non-residents ... and favoring all residents"). 
In virtually no real-world case will all five linkage factors be present. In many real-world cases, however, courts will find linkage and, indeed, must do so under the teaching of existing authorities. We turn now to those authorities and to the application of our analytical structure both to them and to other cases. We begin with cases involving tax credits and exemptions. We turn thereafter to cases involving outright government payments. We look finally at cases involving another related problem: the imposition of a new tax at the same time an old one is repealed or restructured.

\section{Credits and Exemptions}

a. Credits, Exemptions, and the Virtually Per Se Rule. The first type of case that raises linkage issues involves the tax credit or exemption. We saw in our paradigmatic case how one form of credit or exemption was marked by a fatal linkage. When we relax the conditions of our paradigm in a credit or exemption case, constitutional problems persist. The inquiry, however, becomes more complex.

Consider New Energy Co. v. Limbach. ${ }^{174}$ In that case, Ohio provided a credit against the state's motor fuel tax for each gallon of ethanol sold as a component of gasohol. The credit was limited, however, to ethanol produced in Ohio or in a state that granted similar tax benefits to Ohio-produced ethanol. The Court, viewing the tax and the tax credit together, concluded that " $[\mathrm{t}]$ he Ohio provision at issue ... explicitly deprives certain products of generally available beneficial tax treatment because they are made in certain other States, and thus on its face appears to violate the cardinal requirement of nondiscrimination." 175

New Energy, however, did not present all of the indicia of linkage present in our paradigmatic case. In particular, when the legislature adopted the limited ethanol credit, the underlying fuel tax against which the credit operated had been in effect for years. ${ }^{176}$ Hence, the important linkage factor that we call simultaneity was not present in the New Energy case. In addition, the ethanol credit - which by its terms benefited sellers of fuel only to the extent that they sold gasohol - favored only some of the in-state interests bur-

174. 486 U.S. 269 (1988). We discussed New Energy briefly at supra notes 16-20 and accompanying text.

175. 486 U.S. at 274.

176. See 486 U.S. at 272 (noting that the original sales tax exemption was nondiscriminatory, but that the exemption was amended three years later to limit benefits to sellers of local and reciprocity-protected ethanol). 
dened by the underlying fuel tax. The exemption thus lacked universality of scope. 177

The critical message of the New Energy case is that the Court was prepared to, and did, strike down the discriminatory exemption despite the absence of simultaneity and scope. Perhaps the Court was influenced by the fact that as aggregate fuel tax liability rose for ethanol sellers, so too did the credit. For this reason, the taxing scheme in New Energy was marked by the linkage characteristic we call correlation. In reality, however, we doubt that the presence of correlation was key to the result in New Energy, and in fact the Court never mentioned this factor in analyzing the case. Thus, for example, if Ohio had provided a flat fuel tax credit - say, $\$ 1000$ per year - to all sellers of locally produced ethanol, regardless of quantities sold, we believe the Court would have reached the same result.

The reason is that both the actual credit involved in New Energy and our hypothetical $\$ 1000$-per-year credit share a linkage factor so important that it will be dispositive in most tax-credit and taxexemption cases: the factor we call internalization. This factor was present in New Energy - as it is in most cases involving credits or exemptions - because the credit explicitly reduced the tax qua tax. When the legislature itself thus internally ties its "spending" decision to a specific taxing measure, courts should accede to the legislature's own formulation and decline to treat the two state actions as analytically severable.

Before leaving the virtually per se internalization rule, we offer three refinements. First, the principle operates not only in cases that involve exemptions or credits, but also, for example, in cases that involve tax deductions. 178 Even more significantly, we would apply the principle in cases involving true tax rebates - that is, state payments that are tax rebates in the strict sense that the state returns to a taxpayer some or all of the very payment that taxpayer already has made. Such a case, in our view, is in substance the same as one that involves a credit or exemption. More important, our nation's highest tribunal already has reached that conclusion..$^{179}$

177. See supra notes $167-68$.

178. Cf. R.J. Reynolds Tobacco Co. v. City of N.Y. Dept. of Fin., 643 N.Y.S.2d 865 (Sup. Ct. 1995) (finding that limiting favorable depreciation deduction to investments in in-state property violates Commerce Clause); Beatrice Cheese, Inc. v. Wisconsin Dept. of Revenue, [1990-1993 Transfer Binder Wis.] St. Tax Rptr. (CCH) I 203-396 (Wis. Tax App. Commn. Feb. 24, 1993) (same).

179. As Justice Stevens put it in West Lynn Creamery, "[i]t is obvious that the result in Bacchus would have been the same if instead of exempting certain Hawaiian liquors from 
Second, we note that the establishment of linkage by way of internalization - or, for that matter, in any way at all - does not necessarily establish unlawful tax discrimination. Indeed, large numbers of credits or exemptions - even though they are "linked" to a particular tax - do not violate the dormant Commerce Clause, because they do not discriminate against interstate commerce. ${ }^{180}$ Moreover, some credits or exemptions that appear at first blush to be discriminatory turn out not to be discriminatory in an unconstitutional way. We have argued elsewhere, for example, that tax credits or exemptions given with respect to property or sales taxes for businesses that locate operations within a state often should survive dormant Commerce Clause scrutiny despite their superficially discriminatory cast. ${ }^{181}$ In short, the question of linkage is not the same as the question of unlawful discrimination.

Third, we emphasize that our internalization-based virtually per se rule is just that: a virtually per se rule. Thus in proper cases the presumption it establishes may be overcome. ${ }^{182}$ The most obvious case of this sort would involve a legal text that specifically displaces otherwise operative linkage rules. A state constitution's uniformity provision, for example, could contain a proviso that stated: "In no circumstance shall any exemption or credit be considered along with the tax itself in making uniformity determinations." Although such a proviso would be offbeat, its terms would bind the courts.

Was such a provision, in effect, at work in the Westvaco case? We think not. The argument in that case that the Constitution imposed no textual limitation on the "distribution" of taxes but only on the "assessment of property" fell flat because in Westvaco there never was any "distribution" of taxes. Taxpayers simply received a property tax bill reduced by the amount of the credit. ${ }^{183}$

Had the South Carolina Supreme Court been confronted with the facts of the Torphy case, however, the argument against linkage might have won the day because of the language of the South

tax, Hawaii had rebated the amount of tax collected from the sale of those liquors." 512 U.S. 186, 197 (1994). Stated more bluntly, "a discriminatory tax rebate is unconstitutional." 512 U.S. at 197; see also Ragsdale v. Department of Revenue, 895 P.2d 1348, 1356 (Or.) (stating, following Supreme Court's decision in Davis, "[a] tax rebate . . program only for state employees clearly would be impermissible"), cert. denied, 116 S. Ct. 569 (1995).

180. This was the case, for example, with the general exemption of ethanol sales involved in New Energy prior to the statute's amendment in 1984. See 486 U.S. at 272.

181. See Hellerstein \& Coenen, supra note 15, at 825-34.

182. Cf. Maine v. Taylor, 477 U.S. 131 (1986) (finding dormant Commerce Clause virtually per se rule overridden on facts presented).

183. See supra note 111 and accompanying text. 
Carolina Constitution, even if internalization was present. ${ }^{184}$ In Torphy, it will be recalled, ${ }^{185}$ the tax credit received by property owners was not an actual reduction in their local property tax bill (as it was in Westvaco) but rather a payment to the taxpayer by the state. Because the payment was "integrated to the property tax process,"186 the Torphy court reasonably could conclude, as it did, that the taxing and spending measures together violated Wisconsin's constitutional requirement that "[t]he rule of taxation shall be uniform."187 But it does not ineluctably follow that the payment would violate South Carolina's quite different constitutional requirements that "[t]he assessment of all property shall be equal and uniform"188 and that "[p]roperty tax levies shall be uniform." 189 The specific language of the South Carolina Constitution - directed to assessment of property and to property tax levies might well permit a court to conclude that the actual distribution of state funds to property owners did not violate those constitutional strictures. Under these circumstances, the South Carolina Supreme Court would have had more justification than it had in Westvaco for concluding that the taxing-and-spending scheme was acceptable, because the South Carolina Constitution does not limit "distributions" of governmental revenues. ${ }^{190}$ In short, a government payment may violate a constitutional rule that "taxation shall be uniform" but not one that requires uniformity in property tax "assessments" or "levies."

b. Credits, Exemptions, and the Twin-Indicia Rule of Thumb. New Energy and kindred cases ${ }^{191}$ leave no doubt that internalization is a key factor in assessing constitutional linkage questions. Is it nonetheless possible to relax the conditions of our paradigmatic example by removing the factor of internalization while still retaining a tight enough relationship between a taxing measure and a tax credit or exemption to justify their joint consideration? Maryland v. Louisiana ${ }^{192}$ shows that the answer to this question is "yes." In

184. But cf. supra note 114 (suggesting that Torphy might more properly have been characterized as a "subsidy" case than a "credit" case).

185. See supra notes 113-19 and accompanying text.

186. State ex rel. La Follette v. Torphy, 270 N.W.2d 187, 191 (Wis. 1978).

187. Wis. Const. art. VIII, $\S 1$.

188. S.C. Const. art. X, $\S 1$ (emphasis added).

189. S.C. Const. art. $X, \S 6$ (emphasis added).

190. See supra notes 107-11 and accompanying text.

191. See supra notes 10-11 and accompanying text (discussing Bacchus and Westinghouse cases).

192. 451 U.S. 725 (1981). 
that case, Louisiana imposed a tax on the "first use" of any gas imported into Louisiana that had not previously been subjected to tax elsewhere. At the same time it enacted the tax, however, the state put in place a series of credits and exemptions that effectively insulated large numbers of Louisiana producers and consumers from the impact of the tax. Some of these measures were enacted "[u]nder the specific provisions of the First-Use Tax"; 193 others were "enacted as part of the First-Use Tax package."194 The credits, however, did not reduce the First-Use Tax itself but instead reduced other taxes owed to Louisiana. For example, under the severance tax credit, a taxpayer paying the First-Use Tax received an equivalent tax credit on any state severance tax owed in connection with production in Louisiana. As a result, the state's payments (in the form of tax credits and exemptions) were not "internalized" with respect to the First-Use Tax that was subject to challenge in the case. Internalization was present only in the weak sense that both the First-Use Tax and the payments based upon it (in the form of credits and exemptions) were components of the state's overall taxing system. ${ }^{195}$

In addition to their lack of internalization, the credits and exemptions involved in Maryland $v$. Louisiana clearly lacked universality of scope because some Louisiana producers or consumers still paid First-Use Taxes that were not offset by the credits or exemptions. ${ }^{196}$ The Court nevertheless concluded that "the Louisiana First-Use Tax unquestionably discriminates against interstate commerce in favor of local interests as the necessary result of various tax credits and exclusions." 197

193. 451 U.S. at 756.

194. 451 U.S. at 756.

195. While there was no internalization of the credit scheme at issue in Maryland $v$. Louisiana with respect to the First-Use Tax under attack, one could argue that the severance tax (against which First-Use Tax payments were credited) was itself unconstitutional because of internalization. In other words, reduction of the severance tax qua severance tax was conditioned on specific in-state activity, to wit, making a taxable "first use" of natural gas in Louisiana. In Maryland v. Louisiana itself, the state was not attacking the severance tax because, among other things, it lacked standing to do so; its standing was based on the fact that it bore the economic burden of the First-Use Tax, both in its own right and as parens patriae. See 451 U.S. at 736-39. Indeed, it was precisely the lack of severance tax liability that gave the First-Use Tax its bite for the First-Use taxpayers in the case. If such taxpayers had had preexisting severance tax liability, the First-Use Tax would not have imposed upon them any additional tax burden.

196. In particular, the tax credit did not benefit any in-state taxpayers required to pay First-Use taxes but not obligated to pay any severance tax. See 451 U.S. at 756-57.

197. 451 U.S. at 756. See generally Walter Hellerstein, State Taxation in the Federal System: Perspectives on Louisiana's First Use Tax on Natural Gas, 55 TUL. L. REv. 601 (1981). 
Maryland $v$. Louisiana suggests that courts may well find linkage between a tax and a spending measure - that comes in the form of a credit or an exemption - even though (1) the credit is not against the tax itself but against some other tax, and (2) the credits and exemptions do not apply to all members of the favored class of taxpayers. In Maryland v. Louisiana, it was enough to establish linkage that there was simultaneity and strong correlation. Strong correlation existed because (1) the amount of the "payment" the credits and exemptions afforded - for example, in the form of severance tax reductions - was a direct function of the amount of the First-Use Tax paid (thus, there was computational correlation) and (2) the duration of credits and exemptions necessarily was tied to the duration of the First-Use Tax because they were claimable only to the extent the taxpayer paid the First-Use Tax (thus, there was durational correlation). In these circumstances, the Court deemphasized - to the point of apparent irrelevance - the absence of the scope factor created by the inability of some Louisiana First-Use taxpayers to take advantage of the credits and exemptions. With respect to this factor, the Court decreed: "[W] need not know how unequal the Tax is before concluding that it unconstitutionally discriminates."198

In our view, Maryland v. Louisiana illustrates the operation of our Principle \#2 twin-criteria rule of thumb in the credit or exemption context. Even absent internalization, two of the remaining three objective indicia were enough to establish linkage. Simultaneity and strong correlation sufficed to trigger a finding of unlawful tax discrimination.

c. Credits, Exemptions, and the Five-Factor Analysis. Does the foregoing analysis suggest that unconstitutionality lurks in all tax credits and exemptions confined to a class of beneficiaries who could not constitutionally be favored by way of a discriminatory tax rate? In other words, if a state may not enact taxing measures that favor residents over nonresidents, or local businesses over interstate businesses, or state retirees over federal retirees - for example, by imposing a tax only upon nonresidents, interstate businesses, or federal retirees - can the state ever accomplish the same objective by enacting a facially nondiscriminatory tax and then providing the favored group with a credit or an exemption related to the tax?

If the credit or exemption is given against the particular tax in question, the answer is almost always "no" because of the operation

198. 451 U.S. at 760. 
of the virtually per se strong-internalization rule. In such a case, even the lack of simultaneity cannot cut the link forged by state lawmakers themselves. If the credit or exemption is given with respect to some other tax, however, the answer is less certain.

Suppose an income tax is imposed on all residents and nonresidents, but a credit equal to the income tax is granted to homeowners against property taxes due on their principal residence. Does this taxing scheme violate the Privileges and Immunities Clause on the ground that income tax obligations are effectively less for residents than nonresidents? Perhaps not.

In this case, there is strong correlation for exactly the same reasons that strong correlation existed in Maryland $v$. Louisiana. In particular, there is durational linkage because the property tax credit will last only as long as the income tax, and there is computational correlation because the property tax is reduced on a dollarfor-dollar basis as income taxes are paid. ${ }^{199}$ Thus, the other linkage factors - including simultaneity and scope - will play a critical role in our case. If, as in Maryland v. Louisiana, the legislature enacted the taxing and "spending" measures together as part of a single legislative action, the case for treating the two as linked, and thus constitutionally suspect, is so strong that we would apply the rule of thumb embodied in our Principle \#2. In particular, simultaneity brings into play the same political process argument the Supreme Court found supportive of linkage in West Lynn Creamery: The risk of legislative abuse in laying the tax is heightened because many in-state residents who would otherwise oppose it are "mollified" through contemporaneous enactment of the homeowner credit. ${ }^{200}$ If, on the other hand, the state implements the homeowners' property tax credit years after the income tax, perhaps in a year of a large budget surplus, the case for treating the two measures as linked becomes much weaker.

In particular, this change in the facts would negate the operation of the rule of thumb in our homeowners' credit hypothetical because, in the absence of simultaneity, strong correlation would stand alone as an objective linkage factor. Under these circumstances, there is not the sort of universality of scope that was present in our paradigmatic case. In our paradigm, after all, the state imposed its tax generally on residents and nonresidents, and all residents received the benefit of the exemption or the credit. Hence,

199. See supra text following note 170 .

200. See supra note 44 and accompanying text. 
the tax and the tax relief provision worked in lockstep to create a scheme that in appearance and in fact discriminated blatantly against nonresidents.

In our homeowners' credit hypothetical, as in our paradigm, the state lays its income tax on residents and nonresidents alike. In contrast to the paradigm, however, only some residents - namely, those who own a principal residence that generates property tax liability - reap the benefit of the credit. This much looser fit between the class of in-state taxpayers and the class of credit recipients weakens the case for finding linkage as a matter of both form and function. There now are in-state surrogates to represent the interests of burdened outsiders - namely, all of the many state residents who do not own and pay taxes on a home. ${ }^{201}$

In short, using our methodology, the only basis for finding linkage in our hypothetical case would be under the Principle \#3 five-factor analysis. Moreover, because we detect no clear policy concerns that favor a finding of linkage, we would conclude that no linkage exists.

Working through cases subject to Principle \#3 inevitably will present analytical challenges. Assume, for example, that a state grants a total exemption from sales or use taxes for the purchase of industrial equipment for in-state use, but further provides that the credit will operate only so long as the state's corporate income tax remains in effect. Perhaps, because of this durational link, a court would characterize the otherwise constitutionally unobjectionable sales and use tax exemption ${ }^{202}$ as a de facto income tax exemption susceptible to dormant Commerce Clause attack. ${ }^{203}$ The case for thus characterizing the exemption would gain even more momentum if the amount of the tax break corresponded with the income tax - for example, if instead of providing a full-scale sales and use tax exemption, the state afforded a credit that constituted ten percent of income taxes paid. In our view, the combination of strong forms of durational correlation and computational correlation in this case gives rise to a respectable argument for linkage, even absent strong internalization, simultaneity, and universality of scope.

201. See supra note 44 and accompanying text.

202. See Hellerstein \& Coenen, supra note 15, at $829-34$ (discussing businessdevelopment-based relief from sales and use taxes).

203. See id. at 817-20 (discussing Westinghouse case and corporate income tax exemptions). 
Perhaps, in the end, the case would turn on the decisionmaker's sense of sound policy. Some judges, in particular, would be unable to find a fair distinction between our hypothetical corporateincome-tax/sales-or-use-tax-exemption case and Westinghouse Electric Corp. v. Tully. ${ }^{204}$ They would strike down the program in light of the Court's oft-expressed condemnation of tax laws that "encourage out-of-state firms to compete in the [state]" because "such promotion of in-state markets at the expense of out-of-state ones furthers the 'economic Balkanization' that our Dormant Commerce Clause jurisprudence has long sought to prevent."205

As the foregoing discussion reveals, once one substantially departs from the paradigmatic case of a tax credit or exemption enacted along with and exactly offsetting the underlying tax - in which there is no need to balance one linkage factor against another because they all sit on the same side of the scale - the need arises to canvass other relevant factors to determine whether a taxing measure and a spending measure make up, for constitutional purposes, an integrated whole. For example, the "fit" in New Energy and Maryland v. Louisiana between the tax and the tax credit was not as tight as it was in our paradigmatic case because some local businesses still paid, without any relief, the underlying tax. Even so, in both cases, the Court treated the tax and credit as linked - and properly so in our judgment - because of other factors: New Energy demonstrated strong internalization, and in Maryland $v$. Louisiana there was the combination of simultaneity and correlation, together with at least a weak form of internalization. In our homeowner tax credit hypothetical, ${ }^{206}$ by contrast, the combination of non-internalization, non-simultaneity, and nonuniversality-of-scope could easily lead a court to conclude that the taxing and spending measures are not linked, even though their "net effect" seems to be the imposition of a discriminatory burden on nonresidents. On the other hand, strong correlation and considerations of policy might lead a court to find linkage in our corporate-income-tax/sales-or-use-tax-exemption hypothetical.207 If so, a linkage would exist - as it may in other cases that involve application of our Principle \#3 five-factor analysis - even in the

204. 466 U.S. 388 (1984) (invalidating tax credit afforded to corporate income tax payers based on their location of export operations within taxing state).

205. Fulton Corp. v. Faulkner, 116 S. Ct. 848, 855 n.3 (1996) (quoting Hughes v. Oklahoma, 441 U.S. 322, 325 (1979)); see also Maryland v. Louisiana, 451 U.S. 725, 757 (1981).

206. See supra text following note 198.

207. See supra notes 201-03 and accompanying text. 
absence of strong internalization, simultaneity, and universality of scope.

d. Credits, Exemptions, and Federal-Taxation-Related Policy. We have just seen how the policies that drive tax-discrimination rules may influence judicial resolution of linkage questions. ${ }^{208} \mathrm{We}$ also have seen, and will continue to see, that there is a variety of such policies that may come into play. ${ }^{209}$ There is, however, one potential policy-driven principle that deserves extended treatment because the Supreme Court itself has suggested its centrality. This principle - if it is a principle - emanates from the intergovernmental-tax-immunity decision in Davis, in which eight Justices relied on federal income tax law to rebuff Justice Stevens's argument that the Court should treat a state-retiree income tax exemption no differently from a state-retiree benefit increase. ${ }^{210}$ What are the implications of this aspect of Davis on linkage analysis with respect to state tax credits and exemptions?

Assume, for example, that a state grants an income tax exemption for all monies paid to contractors for work on state, but not on federal or private, construction projects. At first blush, this exemption seems to run head on into the Davis principle, which focused on discriminatory tax advantages afforded by the state to "those with whom it deals itself."211 Justice Stevens, however, would surely object to invalidation of a state-contractor exemption on this ground no less vigorously than he objected to invalidation of the state-retiree exemption in Davis. ${ }^{212} \mathrm{He}$ would argue that it "trivializes the Supremacy Clause to interpret it as prohibiting the States from providing through this limited tax exemption what the State has an unquestionable right to provide through increased [contract payments]."213

As we have seen, when Justice Stevens advanced this argument in Davis, the majority parried his thrust by citing federal tax law. Specifically, the majority distinguished a retirement benefit increase from the grant of an exemption for retirement income on the ground that the award of the exemption was "at the expense of the

208. See supra notes 202-05 and accompanying text.

209. See supra notes 171-73 and accompanying text.

210. See Davis v. Michigan Dept. of Treasury, 489 U.S. 803 (1989); see also supra notes 64-65 and accompanying text.

211. 489 U.S. at 815 n. 4 (intemal quotation marks omitted) (quoting Phillips Chem. Co. v. Dumas Indep. Sch. Dist., 361 U.S. 376, 385 (1960)).

212. See supra notes 58-62 and accompanying text.

213. Davis, 489 U.S. at 824 (Stevens, J., dissenting). 
federal treasury," 214 given that the increased retirement benefit would be subject to federal income tax whereas the exemption would not.215 This response to Justice Stevens's "trivialization" argument, however, does not carry over to the state-contractor case because the federal tax consequences of a state-contractor tax exemption turn out to be very different from the tax consequences of a state-retiree tax exemption. Indeed, the federal income tax consequences of affording a state contractor a state income tax exemption are no different at all from the federal tax consequences of increasing the contractor's compensation in an amount necessary to place it in the same economic position it would enjoy under the exemption.

To be sure, any increase in the contractor's compensation drives up federal tax revenues by increasing the contractor's taxable income. The state's grant of an equivalent state tax exemption, however, drives up the contractor's federal taxable income in precisely the same amount because federal law gives federal taxpayers a deduction for state tax payments. In other words, because the grant of a state tax exemption removes an otherwise available federal tax deduction, the grant of such an exemption operates - no less than the award of additional compensation - to increase federal taxes. 216

At first glance, this analysis suggests that the majority erred in Davis itself when it posited that the state-retiree tax exemption at issue generated less federal tax revenue than would an equivalent state-retiree benefit increase. After all, state taxes paid by state retirees are every bit as deductible on federal returns as state taxes paid by state contractors. ${ }^{217}$ There is, however, an important difference between the two cases: Building contractors' state income tax

214. 489 U.S. at 815 n.4.

215. Alternatively, one might say that the tax exemption for state retirement income allowed the state to reduce its compensation to state employees, thereby reducing federal tax revenues.

216. Assume, for example, $\$ 100$ of contractor income, a state corporate income tax rate of $10 \%$ (about equal to the present rate in California, New York, and Pennsylvania, see 1 Multistate Corporate Income Tax Guide (CCH) I 170 (1996)), and a federal corporate income tax rate of $34 \%$, see I.R.C. $\$ 11$ (b) (1994). If the contractor's income is exempt from state taxes, the contractor pays $\$ 34$ in federal taxes and keeps $\$ 66$. To maintain the contractor in the same economic position if the state were to eliminate the exemption, the state would have to increase its contract payments to $\$ 111.11$. In this case, the contractor would receive $\$ 111.11$ in compensation, pay $\$ 11.11$ in state taxes, which it would deduct for federal tax purposes, leaving the contractor with $\$ 100$ of federal taxable income, $\$ 34$ of which would be remitted to the Internal Revenue Service. The contractor would thus end up with the same $\$ 66$ it retained under the state tax exemption. In both cases, the federal government receives the same $\$ 34$ in taxes.

217. See infra note 219 and accompanying text. 
payments constitute deductible business expenses ${ }^{218}$ that always reduce federal taxable income; retirees' state income tax payments, in contrast, constitute personal expenses ${ }^{219}$ that reduce federal taxable income only when claimed as itemized deductions. ${ }^{220}$ In fact, federal retirees often claim the standard deduction rather than itemizing personal deductions. Thus the state's grant of a retirement-income tax exemption is different from a retirement-benefit payment increase, because the award of the tax exemption unlike the benefit increase - does not influence a nonitemizing taxpayer's federal tax bill.

For this reason, our state-contractor case poses in stark terms the question whether the Court in Davis meant what it said when it leaned on the operation of federal tax law to answer Justice Steven's it's-just-like-a-payment critique. If the Court actually confronted our state-contractor exemption, would it stick with its federal-tax-impact reasoning, deem the exemption indistinguishable from a payment increase, distinguish Davis on this ground, and thus find no intergovernmental tax immunity problem? We doubt it.

If we are right, it means the Court someday must retract its federal-tax-driven response in Davis to Justice Stevens's it's-justlike-a-payment analysis. Perhaps a better answer to the Davis dissent would have been to say that the outright award of cash benefits is more visible and subject to political checks - and thus less likely to generate unjustified discrimination - than the grant of a tax exemption. 221 An even better response to the Davis dissent, however, would have focused on the factor of internalization - a linkage characteristic that both the state-retiree income tax exemption in Davis and our hypothetical state-contractor income tax exemption have in common.222 In particular, we would say that our hypothetical state-contractor case - like Davis itself - was subject to the virtually per se rule of linkage triggered by strong internalization. We also would say that it reflects unsound constitutional policy to let linkage determinations - in intergovernmental tax immunity or other tax-discrimination cases - hinge on the subtle and ever-shifting intricacies of federal income tax law.

218. See I.R.C. §§ 162(a), 164(a) (1994).

219. See I.R.C. § 164(a) (1994).

220. See I.R.C. §§ 62-63 (1994).

221. See West Lynn Creamery, Inc. v. Healy, 512 U.S. 186, 211-12 (1994) (Scalia, J., concurring in the judgment) (noting commentators' reliance on this point in defending most state business subsidies against dormant Commerce Clause attack).

222. See supra text accompanying notes 210-11. 


\section{Outright Government Payments}

a. Payments and the Twin-Indicia Rule of Thumb. When we leave the realm of tax credits and exemptions for the realm of direct government payments, we immediately confront one major difference that is critical to linkage analysis: Because there is no reduction in any tax qua tax, neither the factor of internalization nor the virtually per se rule it triggers ${ }^{223}$ can apply to such cases. ${ }^{224}$ To be sure, there may be circumstances - as the foregoing discussion has indicated 225 - when a tax and a subsidy are so closely "conjoin[ed]" 226 in "an integrated regulation" 227 that the court will find an unconstitutional linkage. In general, however, the absence of internalization in both the strong and weak senses - through reduction of the tax in question or the reduction of some other tax - substantially undercuts the case for linkage whenever the state makes outright payments of cash.

The point is illustrated by comparing the result in New Energy, in which the Court found a link between Ohio's nondiscriminatory motor fuel tax and its credit against that tax for locally produced ethanol, with the result that would have ensued if the state had effectuated its spending program by way of a subsidy rather than a credit. In a unanimous opinion, the Court in New Energy declared:

It has not escaped our notice that the appellant here, which is eligible to receive a cash subsidy under Indiana's program for in-state ethanol producers, is the potential beneficiary of a scheme no less discriminatory than the one that it attacks, and no less effective in conferring a commercial advantage over out-of-state competitors. To believe the Indiana scheme is valid, however, is not to believe that the Ohio scheme must be valid as well. The Commerce Clause does not prohibit all state action designed to give its residents an advantage in the marketplace, but only action of that description in connection with the State's regulation of interstate commerce. Direct subsidization of domestic industry does not ordinarily run afoul of that prohibition; discriminatory taxation of out-of-state manufacturers does. 228

The Court's assertion that "[d]irect subsidization of domestic industry does not ordinarily run afoul of [the dormant Commerce Clause] prohibition" 229 makes an important, though implicit, state-

223. See supra text accompanying notes $150-51,157-59$.

224. But cf. infra text accompanying notes $240-42$ (discussing true tax rebates).

225. See supra notes $26-30$ and accompanying text.

226. West Lynn Creamery, 512 U.S. at 199.

227. 512 U.S. at 201.

228. New Energy Co. v. Limbach, 486 U.S. 269, 278 (1988).

229. 486 U.S. at 278. 
ment about linkage analysis. Even though a tax credit and a subsidy may carry with them economically equivalent effects, ${ }^{230}$ there are circumstances in which courts will invalidate only the tax credit under the Commerce Clause because only the tax credit constitutes what the Commerce Clause forbids - state regulation, in the form of taxation, of interstate commerce. ${ }^{231}$ In other words, the very nature of a tax credit or exemption is that it intertwines with a tax; thus it is subject to constitutional analysis as an integral component of that tax. A subsidy, by contrast, may have strong enough connections to a taxing measure to qualify as part of an "integrated regulation," 232 but according to both New Energy and West Lynn Creamery this will not "ordinarily" be the case.233

What, then, should the law require to turn the "ordinarily" benign government subsidy into an integral part of a discriminatory tax program? Insofar as West Lynn Creamery is our guide, it emphasizes one linkage factor we have identified above: simultaneity..$^{234}$ The Court relied on the political dynamics of the enactment of the taxing and spending measures as the glue that held them together for constitutional purposes. ${ }^{235}$ As it did so, however, the Court paid no attention to the absence of other linking factors that we have identified as significant. First, there was no internalization of the spending measure and the tax - no tax qua tax was reduced by the subsidy. Second, the spending measure lacked a universal scope of coverage. Indeed, the spending measure not only failed to provide relief from the burden of the levy to all those who dealt with the favored product - dealers in-state milk - it favored a wholly different class of in-state beneficiaries - in-state producers who were never subject to the tax at all.236 Perhaps the key to West Lynn Creamery is that, on close inspection, there was a significant

230. See Hellerstein \& Coenen, supra note 15, at 835.

231. See id. at 794 (setting forth authorities holding that taxation is a form of regulation for purposes of dormant Commerce Clause).

232. West Lynn Creamery, 512 U.S. at 201.

233. See 512 U.S. at 199 n.15 (quoting New Energy, 486 U.S. at 278). The West Lynn Creamery case is discussed supra notes $21-41$ and accompanying text.

234. See supra text accompanying notes 160-65.

235. See supra note 44 and accompanying text.

236. Of course, one could say that the tax burden and subsidy benefit would be passed back and forth between the dealers and producers in a way that would minimize the practical significance of this nonalignment. The Court, however, often has hesitated to assume that these sorts of pass-throughs occur. See, e.g., Fulton Corp. v. Faulkner, 116 S. Ct. 848, 859 (1996) (citing "the frequently extreme complexity of economic incidence analysis"); McKesson Corp. v. Division of Alcoholic Beverages \& Tobacco, 496 U.S. 18, 47 (1990) ("[D]etermining whether a particular business cost has in fact been passed on to customers or suppliers entails a highly sophisticated theoretical and factual inquiry ...."). 
correlation between the milk payments and the milk tax. In particular, there existed both source correlation, because all milk payments came out of a fund made up entirely of milk tax proceeds, and durational correlation, because given the specific source of the subsidies they could be paid out only so long as the state imposed the milk tax. These factors established strong correlation. Thus, because West Lynn Creamery involved both simultaneity and correlation, the case fell within our twin-indicia rule of thumb.237

While the Court's decision in West Lynn Creamery is helpful to the extent that it signals some factors that should inform the linkage inquiry, it is less than helpful in indicating how courts should balance various linking factors against one another. Beyond the bland admonition that "our cases have eschewed formalism for a sensitive, case-by-case analysis of purpose and effects," 238 one finds in West Lynn Creamery no explicit guidance as to the relative weight courts should accord relevant linkage criteria. Perhaps the principal practical teaching of West Lynn Creamery - although it is one that is implicit rather than explicit - lies in the notion that simultaneity is a central factor in subsidy cases. Because internalization is never present in the subsidy context, ${ }^{239}$ simultaneity assumes a much greater relative importance when government spending measures take the form of outright payments than when government spending measures take the form of credits or exemptions.

b. Payments, Close Rule-of-Thumb Cases, and Five-Factor Analysis. To say that simultaneity is important in outright spending cases is not to say that it is a sine qua non of establishing linkage between a tax and an outright-spending measure. Consider this variation on our paradigmatic case: In Year 1, the state puts in place an income tax payable by all individuals who earn income in the state at a rate of five percent. In Year 2, the state enacts separate legislation giving every state resident a "subsidy" equal to five percent of income.

237. We acknowledge that this conclusion is debatable since the correlation involved in West Lynn Creamery was not as strong as it might be, given the probable absence of computational correlation. Even if West Lynn Creamery were a Principle \#3 case, however, we would find linkage in light of the likely presence of some measure of de facto scope and strong policy responsiveness. For a detailed development of the role of the policy responsiveness criterion in West Lynn Creamery and other dormant Commerce Clause subsidy cases, see Coenen, supra note 51, at 36-56 (discussing West Lynn Creamery) and id. at 56-70 (discussing other dormant Commerce Clause cases). See also Hellerstein \& Coenen, supra note 15 , at 834-70 (discussing arguments for and against invalidating various forms of business development subsidies).

238. West Lynn Creamery, 512 U.S. at 201.

239. But cf. supra notes $178-79$ and accompanying text (discussing the presence of internalization in tax rebates). 
Does this "subsidy" provide the sort of de facto discriminatory tax relief that runs afoul of the Privileges and Immunities Clause? Notwithstanding the absence of simultaneity, we think that it does, because it triggers the twin-indicia rule of thumb. There is true universality of scope because all residents, and only residents, enjoy the benefit of the spending program. Likewise, in our view, there may well be sufficiently strong correlation. Although there is no durational correlation - and probably no source correlation either - the facts reveal very powerful computational correlation. This is the case because the tax base and "subsidy base" are exactly the same: each is a function of annual income. Moreover, the modes of calculating the subsidy and tax also are identical: each is a percentage of income; indeed, each is exactly five percent. In our view, this common-base/common-formula version of correlation reflects the highest degree of computational correlation, in that it resembles something like strong internalization itself. ${ }^{240}$ In other words, there exists a propinquity between the true rebates that trigger the virtually per se rule ${ }^{241}$ and subsidies that in their nature are, like rebates, a mathematical function of a particular tax. If our virtually per se rule of internalization almost applies based on computational correlation alone, then surely it seems logical that the twin-indicia rule of thumb should kick in because universality of scope also is present. Even if the twin-indicia rule were deemed inapplicable, however, we would find linkage in this case. Why? Because the fifth and final factor - policy responsiveness - strongly favors a finding of linkage. In particular, our two-year tax-and-subsidy hypothetical presents exactly the same all-residents-are-favored policy-based argument we found instructive in finding a Privileges and Immunities Clause violation in our paradigmatic case..$^{242}$

Strong correlation may also support linkage, despite the lack of simultaneity, in dormant Commerce Clause cases. Elsewhere we have posited the case in which "State A charges a one percent tax on all goods sold at wholesale" and, by way of legislation enacted at a different time, also "provides a one percent-of-wholesale-price cash subsidy for goods produced within the state."243 In this case, there is no internalization, no simultaneity, and no universality of scope because some businesses that are not subject to tax namely, those that sell their products outside the state - nonethe-

240. See supra text accompanying notes 150-51, 157-59.

241. See supra notes 178-79 and accompanying text.

242. See supra note 171-73 and accompanying text.

243. Hellerstein \& Coenen, supra note 15, at 863. 
less can cash in on the subsidy. We would nonetheless find linkage based largely on the same intense form of correlation present in our privileges and immunities hypothetical: The tax base and "subsidy base" are precisely the same because both the tax and subsidy are a function of wholesale revenues, and both the tax and the subsidy are computed in the same way because each is a fixed percentage of such revenues. We believe that such strong signals of correlation when coupled with a scope that is marked by intrastate overinclusiveness ${ }^{244}$ - suffice to establish linkage. At the least, however, the case lies "close enough to West Lynn Creamery to raise some judicial eyebrows." 245

c. A Return to Ragsdale. Having marked the outlines of proper linkage analysis, we return to the difficult intergovernmental tax immunity issue raised by the Sheehy and Ragsdale cases. ${ }^{246}$ Those cases presented the question whether a benefit increase for state retirees should be deemed a de facto tax rebate when enacted simultaneously with the state's repeal of a state-retirement-income exemption, as an effort to conform with the Davis ruling. Addressing this question, the court in Sheehy - but not the court in Ragsdale - found a constitutional violation.

In our view, the court in Sheehy was right, and the court in Ragsdale was wrong. In the next three sections, we explain this conclusion, using the five-factor linkage methodology we have developed in the preceding pages. In the first of these sections, we consider whether the court in Ragsdale should have found West Lynn Creamery dispositive on the linkage question. After identifying conflicting signals on this point, we turn in the next section to application of the twin-indicia rule of thumb. Then, having concluded that the rule of thumb probably was inapplicable in Ragsdale, in the final section we apply to the case our more wideranging five-factor mode of analysis. Paying particular attention to policy responsiveness, we conclude that the court in Ragsdale reached the wrong result.

i. Ragsdale and West Lynn Creamery. A proper way to begin analysis of Ragsdale is to ask whether that case was squarely controlled by the essentially contemporaneous Supreme Court decision in West Lynn Creamery. Clearly there is a tension between the cases. ${ }^{247}$ This tension arises because the court in Ragsdale refused

244. See supra note 169 and accompanying text.

245. Hellerstein \& Coenen, supra note 15, at 864.

246. See supra notes $68-103$ and accompanying text.

247. See supra notes $96-101$ and accompanying text. 
to treat as a "tax rebate" a benefit increase for state retirees that was enacted simultaneously with the state's imposition on them of its income tax. In West Lynn Creamery, however, the Court did characterize as a "tax rebate" a state subsidy awarded to state dairy farmers precisely because it was put in place simultaneously with the state's imposition of a milk tax. ${ }^{248}$ Can this tension be dispelled by constructing some logical distinction between the two cases?

Justice Scalia might say that the use of a segregated fund in West Lynn Creamery served to distinguish that case from Ragsdale. ${ }^{249}$ This suggested distinction seems weak, however, because Ragsdale also involved a segregated fund in that the state paid its additional pension benefits out of its separate pool of retirement monies. ${ }^{250}$ Even more important, only Justice Scalia (joined by Justice Thomas) stressed the state's use of a segregated fund in West Lynn Creamery. ${ }^{251}$ Because the majority in that case assigned the segregated-fund factor no significance whatsoever, it provides a most unlikely basis for constructing the key distinction between West Lynn Creamery and Ragsdale.

A more promising basis for distinguishing the two cases lies in the Court's reasoning in Davis. As we have seen, the Court in that case stated that a state-retiree tax exemption was different than a state-retiree benefit increase because the latter form of relief was less invasive of federal tax collections. ${ }^{252}$ It thus comes as no surprise that, in upholding the pension benefit increases at issue in Ragsdale, the court pointed to their federal taxability. ${ }^{253}$

Prior analysis reveals why a milk-producer subsidy is not distinguishable from a milk-producer tax exemption in terms of its impact on federal tax revenues in the same way that a state pension

248. See supra note 29 and accompanying text.

249. See supra notes $37-39$ and accompanying text.

250. To be sure, the "segregated fund" involved in Ragsdale could be distinguished from the one involved in West Lynn Creamery on the grounds that (1) the tax monies involved in Ragsdale - unlike in West Lynn Creamery - were paid into the general treasury and not channeled into a separate fund, and (2) West Lynn Creamery - unlike Ragsdale - involved construction of a segregated fund entirely out of specific taxes laid on a discrete industry to whose in-state members' benefit the segregated fund inured. See West Lynn Creamery, Inc. v. Healy, 512 U.S. 186, 190-91 (1994); Ragsdale v. Department of Revenue, 895 P.2d 1348, 1356 (Or.), cert. denied, 116 S. Ct. 569 (1995). At the same time, it may be true that the state's channeling of payments out of its segregated retirement fund created a significant check on later political tampering with the payment program. If this was the case, it would cut in favor of likening Ragsdale to West Lynn Creamery on "segregated fund" grounds.

251. See 512 U.S. at 207 (Scalia, J., joined by Thomas, J., concurring in the judgment); see also supra text accompanying notes 37-39.

252. See supra notes 64-65 and accompanying text.

253. See supra note 86 and accompanying text. It is surprising, however, that in doing so the court did not rely on, or even cite, the Davis decision. 
payment is distinguishable from a state pension tax exemption. ${ }^{254}$ It follows that, if a court were to accept the underlying reasoning of Davis, it might well refuse to liken a retirement payment to a retirement benefit exemption, even though the Supreme Court did assimilate a milk subsidy to a milk tax exemption in West Lynn Creamery.

No less important, Davis's expression of concern about state interference with federal tax collections could serve to distinguish Ragsdale from West Lynn Creamery even if federal taxation of milk sales and retirement benefits followed exactly the same pattern that is, even if the award of milk subsidies, like the award of retirement payments, produced more federal tax collections than the award of an otherwise economically equivalent tax exemption. This is the case because West Lynn Creamery concerned the dormant Commerce Clause, whereas Ragsdale involved the intergovernmental tax immunity rule.

This fact matters because of the linkage factor we call policy responsiveness. In particular, it is hard to see how a state's decision to help local businesses in a way that reduces federal taxes increases the danger to the underlying national-common-market goals of the dormant Commerce Clause. ${ }^{255}$ On the other hand, when a state cuts into federal revenue collections by granting its retirees a tax exemption, rather than a benefit increase, such a choice affronts the principle of national supremacy that lies at the root of the intergovernmental tax immunity doctrine. ${ }^{256}$ In short, the federal-tax-based policy considerations invoked in Davis provide a basis for distinguishing Ragsdale from West Lynn Creamery on the simple ground that the two cases involved applications of different doctrines driven by different underlying concerns.

There is, however, a profound difficulty with distinguishing West Lynn Creamery and Ragsdale on this ground, in that Davis's focus on federal taxability was misplaced. We have developed this point at length in discussing tax credits and exemptions. ${ }^{257}$ The essential point of that discussion - that courts should not rely on federal tax

254. See supra notes $214-20$ and accompanying text. In particular, a state's choice of granting a retirement exemption - rather than a comparable retirement benefit increase would produce fewer federal tax revenues because of the availability of the standard deduction. In contrast, a tax exemption for milk dealers inevitably will result in the removal of a business-expense deduction by reason of the negation of an itemized state tax payment. It follows that while additional retirement payments and retirement-payment tax exemptions are unalike for purposes of federal taxation, milk subsidies and milk tax exemptions are very much akin.

255. See supra notes 6-12 and accompanying text.

256. See supra notes $52-56$ and accompanying text.

257. See supra notes 208-22 and accompanying text. 
law in making linkage determinations - applies no less to outright state payments than it does to internalized state tax relief.

ii. Ragsdale and the Rule of Thumb. If there is a genuine basis for distinguishing West Lynn Creamery from Ragsdale, it emerges from application of the twin-indicia rule of the thumb we have developed in this article.258 In West Lynn Creamery, as we have seen, the twin-indicia rule of thumb took hold because the case involved both simultaneity and strong correlation. 259

Ragsdale, like West Lynn Creamery, involved simultaneity because the state repealed its state-retirement-pay tax exemption at exactly the same time the state increased state-retirement-pay benefits. Moreover, Ragsdale - like West Lynn Creamery - did not involve strict universality of scope. ${ }^{260}$ Universality was absent in Ragsdale because some state retirees who paid the newly imposed tax received no benefit increase, while other retirees did receive increases even though they paid no new tax. ${ }^{261}$

Application of the twin-indicia rule of thumb in West Lynn Creamery and Ragsdale thus depended on whether there was strong correlation. West Lynn Creamery presented a powerful case for finding such correlation, because both durational and source-based correlations were identifiable. ${ }^{262}$ In Ragsdale, by contrast, only one of these forms of correlation clearly was at work. There was no source-based correlation because the newly imposed taxes were neither rebated to nor returned in the aggregate to newly taxed state retirees. There also was an absence of strong computational correlation; this was the case because, for each state retiree, any benefit payments were calculated as a function of years of service, rather than of income taxes paid. ${ }^{263}$

In short, the court in Ragsdale - unlike the Court in West Lynn Creamery - confronted only one clear form of correlation: correlation based on the express durational connection between the spending program and the newly imposed tax. ${ }^{264}$ In our view, if there is a plausible distinction between West Lynn Creamery and Ragsdale, this is it. To say there is a plausible distinction, however,

258. See supra notes 223-39 and accompanying text.

259. See supra notes $21-51$ and accompanying text.

260. See supra notes 48-50 and accompanying text (discussing West Lynn Creamery).

261. See supra notes $81-91$ and accompanying text.

262. See supra notes 21-51 and accompanying text.

263. See supra note 84 and accompanying text.

264. See supra notes $81-91$ and accompanying text. 
is not to say that distinction should control if cross-cutting factors undermine it.

iii. Ragsdale and Policy Responsiveness. As we have just seen, the facts of Ragsdale may well not have triggered the twin-indicia rule of thumb. ${ }^{265}$ Reaching that conclusion, however, does not end our linkage inquiry, but merely shifts analysis to the third stage that is, to evaluation of all five linkage criteria, including policy responsiveness.

In our view, proper application of Principle \#3 analysis reveals that the court missed the boat in failing to find linkage in the Ragsdale case. We reach this conclusion in part because, even if that case did not trigger the twin-indicia rule of thumb, the case presented a just-miss set of facts on this score. ${ }^{266}$ Given this circumstance, the fifth linking factor - namely, policy responsiveness takes on particular importance. For three separate reasons, application of this factor leaves little doubt that Oregon's tax reform and spending program were linked in a manner repugnant to the intergovernmental tax immunity principle.

First, the Oregon Supreme Court misstepped by focusing unduly on the notion that "[i]ntergovernmental tax immunity does not require that the state treat state and federal employees the same way[;] it requires only that the state system of taxation be equal."267 In $M^{\prime}$ Culloch v. Maryland, ${ }^{268}$ the Court stated the governing immunity principle more broadly: "States," the Court explained, lack power to "retard, impede, burden, or in any manner control" the operations of the national government "by taxation or otherwise."269 This seminal language cannot change later developments that have focused the intergovernmental immunity doctrine on cases involving taxation. ${ }^{270}$ At least, however, it supports an openstanced approach to viewing state payments as discriminatory forms

265. But cf. infra note 266 .

266. This is because one objective linkage factor - simultaneity - clearly is present while another such factor - correlation - is all but, if not actually, present. There is durational correlation in the clearest possible sense in Ragsdale in that the legislature went out of its way to tie the duration of its benefit award to the continued taxation of state retirement income. The case for strong correlation also may gain strength from the uncontested fact that the state adopted its increased benefit program for the express purpose of offsetting the newly imposed tax. Finally, while there was not a perfect universality of scope in Ragsdale, it is likely that most state retirees did in fact benefit from the state's payment increases. Thus there may well have been substantial universality or something very close to it.

267. Ragsdale v. Department of Revenue, 895 P.2d 1348, 1353 (Or.), cert. denied, 116 S. Ct. 569 (1995).

268. 17 U.S (4 Wheat.) 316 (1819).

269. 17 U.S. at 436 (emphasis added).

270. See supra notes $52-56$ and accompanying text. 
of de facto tax relief in the intergovernmental tax immunity context.

Second and more important, the court's analysis in Ragsdale failed to take account of the law of constitutional remedies. Given Oregon's past undisputed violation of the Davis principle, the Oregon Supreme Court was called upon not only to end the outlawed discrimination, but also to take "affirmative steps to eliminate the effects of a violation of law."271 One effect of the legislature's pre-Davis grant of the discriminatory exemption was its post-Davis award of the benefit increase challenged in the Ragsdale suit. Given this causal nexus, the Oregon Supreme Court's validation of the benefit grant stood in tension with the most basic goal of constitutional remediation: "[T]o restore the victims of discriminatory conduct to the position they would have occupied in the absence of such conduct."272

Finally, the result in Ragsdale seems wrong because it runs counter to the basic policies that underlie the intergovernmental tax immunity doctrine itself. That doctrine "finds its explanation and justification" in "avoiding the potentialities of friction" endemic in state taxation of the national government's operations. ${ }^{273}$ In keeping with the goal of avoiding such friction, the Court has tied the doctrine to the notion of discrimination. Courts will uphold a tax on "those who deal with the Federal Government" only if the tax "is imposed equally on the other similarly situated constituents of

271. Houchins v. KQED, Inc., 438 U.S. 1, 40 (1978) (Stevens, J., dissenting) (stating that this principle has been applied in "situations which are both numerous and varied"); see also Regents of the Univ. of Cal. v. Bakke, 438 U.S. 265, 362 (1978) (opinion of Brennan, White, Marshall, and Blackmun, JJ., concurring in the judgment in part and dissenting in part) (" $\mathrm{A}]$ public body which has itself been adjudged to have engaged in racial discrimination cannot bring itself into compliance with the Equal Protection Clause simply by ending its unlawful acts and adopting a neutral stance."); Swann v. Charlotte-Mecklenburg Bd. of Educ., 402 U.S. 1, 28 (1971).

272. Milliken v. Bradley, 433 U.S. 267, 280 (1977) (emphasis added) (internal quotation marks omitted) (quoting Milliken v. Bradley, 418 U.S. 717, 746 (1974)); see also United States v. Virginia, 116 S. Ct. 2264, 2282 (1996). Notably, if the state had faced this argument in the Oregon courts, the state might have responded that it would have enacted the benefit increase instead of the tax exemption if it had known, when it enacted the exemption, of its illegality. From this premise, it would follow that the Court should not intervene (at least on remedial grounds) because retention of the later-adopted benefit increase would in fact put federal retirees "in the position they would have occupied" absent the illegal tax discrimination. 433 U.S. at 280. The problem with the state's argument is that it hardly comports with our constitutional culture to give exonerating effect to the speculative conjectures of proven violators of the law. See, e.g., McKesson Corp. v. Division of Alcoholic Beverages \& Tobacco, 496 U.S. 18, 42 \& n.24 (1990) (expressing skepticism about state's argument as to how it would have structured tax if it had foreseen constitutional invalidity of exemption, deeming prediction "not easily proved" and "contrived and self-serving" in light of "the many complex variables that affect legislative judgment").

273. City of Detroit v. Murray Corp., 355 U.S. 489, 504 (1958). 
the State."274 In this way federal interests are protected against state overreaching. If, but only if, such a "political check against abuse of the taxing power" 275 is present will the court deem the intergovernmental tax immunity doctrine inapplicable. ${ }^{276}$

The Oregon legislature's response to Davis ran afoul of these guiding principles because of the real-world conditions that prevailed in Oregon after the Supreme Court decided Davis. Following Davis, both state and federal retirees in Oregon in effect enjoyed immunity from state taxation so long as Oregon's tax exemption for state employees remained on the books. 277 Thus, by removing the explicit tax exemption disapproved by Davis, the state effectively imposed a new tax on, and only on, state and federal retirees. Justice Stevens pointed out the constitutional difficulty presented by this form of state action in his Davis dissent: "[A] special tax imposed only on federal and state employees . . . may reflect the type of disparate treatment that the intergovernmental tax immunity forbids because of the ability of the State to adjust the compensation of its employees to avoid any special tax burden on them."278 In Oregon's case, Justice Stevens's concern about the "ability" of the state to offset the tax burden with increased stateretiree compensation proved well founded. The state in fact fully exercised its ability to provide just such an offset, at exactly the same time it imposed the tax, for the very purpose of sheltering state employees from the new burden it imposed.279 In these circumstances, it seems likely that even Justice Stevens - the sole dissenter in Davis - would have found a violation of the intergovernmental tax immunity doctrine in the Ragsdale case.

There is no less reason to suppose that the Davis majority's own discrimination-driven analysis would have led it to find a constitutional wrong in Ragsdale. In Davis, after all, the majority found a

274. United States v. County of Fresno, 429 U.S. 452,462 (1977).

275. 429 U.S. at 463.

276. See, e.g., Massachusetts v. United States, 435 U.S. 444, 457 n.13 (1978) (plurality opinion) ("We have regularly relied upon the existence of ... political checks in considering the scope of the National Government's immunity from state taxation."). Of course, this statement is not directed toward that aspect of the tax-immunity rule that outlaws "direct" taxes on the national government's operations regardless of the discriminatory character of the exaction. See supra note 54.

277. See Davis v. Michigan Dept. of Treasury, 489 U.S. 803, 818 (1989) (emphasizing Court's "mandate of equal treatment" and requirement of "extending the tax exemption to retired federal employees" unless the state "eliminat[es] the exemption for retired state and local government employees").

278. 489 U.S. at 824 (Stevens, J., dissenting).

279. See supra notes $81-91$ and accompanying text. 
violation of the tax immunity rule despite the fact that federal employees were disadvantaged in a fashion identical to the "vast majority" of state taxpayers. ${ }^{280}$ Even in the face of these political dynamics, the majority felt compelled to apply the tax immunity doctrine because the state had singled out its own employees for favored treatment. "The danger that a State is engaging in impermissible discrimination against the Federal Government," the Court explained, "is greatest when the State acts to benefit itself and those in privity with it."281

Following this logic, Oregon - in the wake of Davis - committed two sins, rather than only one. First, in protecting the interests of only state employees, Oregon ignored the principle that, in taxrelated activities, the state must treat "those who deal with the [Federal] Government as well as it treats those with whom it deals itself."282 Second, Oregon selectively protected its own retirees in a setting where the interests of federal workers enjoyed no meaningful protection in the state political process. This was the case because, after Davis, state residents confronted a situation in which in effect both state retirees and federal retirees enjoyed a blanket exemption from state income taxation. ${ }^{283}$ In other words, the full personal income tax burden of the state was to be borne by those whose work was in the private sector. Against this backdrop, federal retirees plainly lacked surrogate protection; private workers and retirees were not about to object when the state lightened their prospective burden by extending its personal income tax to both federal and state retirees - less only the partial offsetting grant of increased benefits to state retirees.

In short, as the Oregon legislature moved to modify its taxing system in response to Davis, federal retirees enjoyed no surrogate protection whatsoever. For this reason, Davis provides an a fortiori argument for invalidation of the combined new-tax-but-morebenefits program at issue in Ragsdale. Put differently, the underlying "danger of discrimination" logic of Davis"284 lends support to

280. See 489 U.S. at 823 (Stevens, J., dissenting).

281. 489 U.S. at 815 n.4.

282. 489 U.S. at 815 n. 4 (quoting Phillips Chem. Co. v. Dumas Indep. Sch. Dist., 361 U.S. 376,385 (1960)).

283. See supra notes $68-72$ and accompanying text.

284. See 489 U.S. at 815 n.4; see also 489 U.S. at 820 n.2 (Stevens, J., dissenting) (citing the Court's continued emphasis on the "political check" provided by contemporaneous taxation of "all other residents and voters of the State" to counteract the fact that "the United States does not have a direct voice in the state legislatures" (quoting United States v. County of Fresno, 429 U.S. 452, $462-64$ (1977); Washington v. United States, 460 U.S. 536, 545 (1983))). 
viewing the purportedly permissible "spending" measure at issue in Ragsdale as unconstitutionally discriminatory tax relief.

iv. A Reprise. There is room for disagreement about the proper result in Ragsdale. At the least, however, the preceding analysis shows how courts can approach outright-payment linkage cases in a more systematic and policy-sensitive manner. We believe that using such an analysis in Ragsdale would have produced a different and better opinion, and perhaps a different result.

\section{Restructuring Relative Tax Burdens}

There is a final category of cases - involving neither tax credits or exemptions nor outright state payments - that any comprehensive treatment of linkage issues must take into account. Suppose, for example, that a state passes a law that imposes a nondiscriminatory tax on everyone who drives an automobile in a state at the rate of a penny per mile. At the same time, however, the state enacts a law that reduces in-state automobile registration fees by an amount that offsets, at least for most in-state automobile owners, the penny-per-mile tax. Would the state's actions amount to the imposition of an unconstitutionally discriminatory tax on outof-state owners of automobiles driven in the state?

A similar question arose in American Trucking Assns. $v$. Scheiner, ${ }^{285}$ which presented the following facts: Many years prior to the case, the state had imposed a registration fee on all in-state trucks. Later, the state imposed a flat axle tax on all trucks using its roads and, at the same time, reduced registration fees on in-state trucks in an amount that, for all practical purposes, was equivalent to the new axle tax.286 Because the state's actions taken together triggered an additional net tax liability only for out-of-state truckers, those truckers argued that the state had violated the Commerce Clause antidiscrimination rule. ${ }^{287}$ In the end the Court did not reach this question because it found that the flat axle tax offended the dormant Commerce Clause regardless of the state's action in decreasing in-state registration fees. ${ }^{288}$ In a dissenting opinion, however, Justice Scalia did address the out-of-state truckers' simul-

285. 483 U.S. 266 (1987).

286. See 483 U.S. at 270-75; 483 U.S. at 304 (Scalia, J., dissenting).

287. See supra notes 6-12 and accompanying text.

288. The Court focused in particular on the unapportioned nature of the tax. Because this feature of the tax imposed a higher per mile burden on interstate than on intrastate trucks, due to the fact that the former traveled fewer miles in the state than the latter, the Court found the tax discriminatory in effect. See American Trucking Assns., 483 U.S. at 28486. 
taneous-registration-fee-reduction argument and found it wanting. He reasoned that "both the axle tax and the reduction in registration fees are independently nondiscriminatory."289 Addressing the challengers' effort to link the two state actions, he emphasized that the case was different from Maryland v. Louisiana. ${ }^{290}$ As Justice Scalia explained:

Pennsylvania provides no exemption from its axle tax for in-state truckers, and does not permit axle tax payments to be used as credits against the registration fee. The axle tax alone - unlike the gas tax in Maryland v. Louisiana - is on its face nondiscriminatory. ${ }^{291}$

In finding no fatal linkage between the imposition of axle taxes and the reduction of registration fees, Justice Scalia thus relied on the same internalization linkage factor we have identified above. For him it was critical that the state's legislation with respect to registration fees did not reduce "on its face" either the axle tax or any other tax obligation. ${ }^{292}$

Justice Scalia was not oblivious to the claim that his position elevated "form" over "substance." 293 His response is instructive:

It may well be that the lowering of the exclusively intrastate registration fee has the same net effect as would a tax credit for the axle tax. But so would have the establishment of the registration fee and the axle tax at their current levels in the first place. To determine the facially discriminatory character of a tax not on the basis of the tax alone, but on the basis of the structure of a State's tax code, is to extend our case law into a new field, and one in which principled distinctions become impossible. What if, for example, the registration fees for Pennsylvania-based barges, rather than trucks, had been reduced in an amount that precisely compensated for the additional revenues to be derived from the increased axle fees? Or what if Pennsylvania had enacted the axle tax without reducing registration

289. 483 U.S. at 304 (Scalia, J., dissenting).

290. See supra notes $192-98$ and accompanying text.

291. 483 U.S. at 304 (Scalia, J., dissenting).

292. We note that Justice Scalia did not use the term "internalization" or expressly consider the relationship of internalization with other linkage criteria. Nevertheless, his view that a tax coupled with an exemption or credit is facially discriminatory, and that "the axle tax alone ... is on its face nondiscriminatory," reflects the judgment that a measure that reduces the tax itself is properly viewed as linked to the tax whereas a measure that simply has the "net effect" of reducing the tax, without directly reducing it, is not properly viewed as "linked" to the tax. 483 U.S. 304-05 (Scalia, J., dissenting).

We also note that one may quibble with our characterization of the registration fee reduction as a "spending" measure in the same way that a credit, exemption, or subsidy may be so viewed. We plead nolo contendere to the charge but believe it is beside the point for present purposes. The essential question addressed in the text is whether the fact that the tax in question is reduced by a related action is a significant indicium of "linkage," a point that does not depend on whether that related action is characterized as a "spending measure" or as a "piece of green cheese."

293. See supra notes $124-44$ and accompanying text. 
fees, and then one year later made a corresponding reduction in truck registration fees? This case, of course, is more difficult than those examples, because the tax reduction and axle tax both apply to the same mode of transport and were enacted simultaneously. However, to inquire whether a tax reduction is close enough in time or in mode to another tax so that "in effect" the latter should be treated as facially discriminatory is to ask a question that has no answer. ${ }^{294}$

Given Justice Scalia's unabashed hostility to the negative Commerce Clause, ${ }^{295}$ it is hardly surprising to find him espousing a strict view of the linkage required to establish that two taxing measures, in combination, impermissibly discriminate against interstate commerce. Nevertheless, his analysis, in a backhanded way, provides support for a number of points we have advanced above. In particular, Justice Scalia acknowledges - just as we have argued that the case for linkage becomes "more difficult" when there is no simultaneity of enactment and something less than universality of scope. ${ }^{296}$ Justice Scalia also acknowledges - as we have urged that a constitutionally cognizable linkage ordinarily does exist when the would-be "spending" measure is marked by internalization, because it reduces a tax obligation directly, even in the absence of simultaneity and universality of scope. ${ }^{297}$

In essence, Justice Scalia rebuffed the taxpayer's effort to link the axle tax and the registration fee out of fear that application of any linkage criteria beyond internalization would invite unduly indeterminate judicial inquiries in too many cases. As the preceding discussion reveals, however, courts repeatedly have declined to take such a strict and wooden view of constitutional linkage. ${ }^{298}$

\footnotetext{
294. American Trucking Assns., 483 U.S. at 305 (Scalia, J., dissenting).

295. See Walter Hellerstein, Justice Scalia and the Commerce Clause: Reflections of a State Tax Lawyer, 12 Cardozo L. REv. 1763 (1991).

296. See American Trucking Assns., 483 U.S. at 305 (Scalia, J., dissenting). The significance of the simultaneity criterion is suggested by Justice Scalia's focus on whether the measures were "close enough in time." 483 U.S. at 305. Justice Scalia's discussion of "Pennsylvania-based barges" - to use our terminology - focuses on the lack of universality of scope. There is no universality in his hypothesized case (or even anything close to universality) because, while the new tax falls on all truckers, the new "spending" program targets local barges, instead of all (or even some) local truckers. Notably, with respect to the factor of scope, Justice Scalia's barge hypothetical is far more problematic than West Lynn Creamery, in which scope was lacking as well. In West Lynn Creamery, there was at least the possibility of strong de facto scope, because, although milk dealers and milk producers are separate entities, their relationship is marked by contractual privity so that the pass-through of taxes or subsidy payments between them was possible and perhaps even likely. But cf. supra note 236 (noting Court's aversion to assuming existence of pass-throughs). The same is not true with respect to the operators of trucks and barges.
}

297. See supra note 294 and accompanying text.

298. Indeed, in Maryland v. Louisiana, 451 U.S. 725 (1981), discussed supra in text accompanying notes 192-98 - the very case Justice Scalia sought to distinguish in American Trucking Assns. - the Court did not invalidate the Louisiana First-Use Tax "on the basis of 
Indeed, Justice Scalia himself looked beyond internalization in West Lynn Creamery, when he found that another linkage factor namely, the state's use of a segregated fund - sufficiently tied the Massachusetts milk subsidy to the state's milk tax to render the state's program as a whole unconstitutional.299

In the end, Justice Scalia's position reflects a concern that, at least in tax-restructuring cases, judicial line-drawing based on the sorts of factors we have identified is too unmanageable, unpredictable, and subject to manipulation by the courts. But few constitutional rules provide ready answers to all questions, and courts in many contexts must and do openly weigh a variety of considerations in resolving constitutional disputes. ${ }^{300}$ Over time, courts applying these criteria can articulate principles that cabin judicial discretion. Indeed, the Court already has deeply involved itself in this process by drawing a strong line in New Energy between traditional tax relief and subsidy payments and by focusing in West Lynn Creamery on simultaneity of enactment. ${ }^{301}$

Justice Scalia is right to suggest that tax-restructuring cases like American Trucking Assns. are a far cry from the case that involves an express exemption from or credit against an otherwise generally applicable tax. ${ }^{302}$ But we are unprepared to say that the sort of tax restructuring involved in American Trucking Assns. - which in real life imposes an additional tax burden only on nonlocal businesses - can never give rise to unconstitutional tax discrimination. The very features of the Pennsylvania restructuring on which Justice Scalia focused made the case highly problematic: the registration fee reduction for in-state taxpayers was adopted at the same time the state increased its "nondiscriminatory" tax (simultaneity); the fee reduction was substantially equal in amount to the tax increase (correlation); and those in-staters who suffered the effects of the tax

the tax alone." American Trucking Assns., 483 U.S. at 305 (Scalia, J., dissenting). Rather, the Court considered the overall "structure of a State's tax code," 483 U.S. at 305, and in particular how the First-Use Tax interacted with other, entirely different state taxing provisions. See supra notes 192-98 and accompanying text.

299. See supra notes 33-39 and accompanying text.

300. See, e.g., United States v. Lopez, 514 U.S. 549, 567 (1995) ("These are not precise formulations, and in the nature of things they cannot be."); Hines v. Davidowitz, 312 U.S. 52, 67 (1941) (considering whether state is displaced by federal statute in the absence of express preemption and concluding that "[i]n the final analysis, there can be no one crystal clear distinctly marked formula"). For a recent example of a constitutional case involving multiple-factor analysis, see BMW of North America, Inc. v. Gore, $116 \mathrm{~S}$. Ct. 1589, 1601-03 (1996).

301. See supra notes $16-20,42-47$, and accompanying text.

302. See supra note 294 and accompanying text. 
increase were precisely those in-staters who benefited from the registration fee reduction (universality of scope).

In other tax-restructuring cases the fit between the imposition of a new tax and the reduction for in-state taxpayers of a preexisting tax will be much looser, so that constitutional concerns become less acute. Assume, for example, that Pennsylvania had repealed a generalized personal property tax at the same time it imposed its new across-the-board axle tax. In such a case the net "bite" of the state's action on in-state truckers would be less severe than its "bite" on out-of-state truckers because the former group would enjoy an immediate benefit from the personal property tax repeal. Even so, we believe that a court would not, and should not, find linkage in such a case, because the linking factors we have identified are not strongly at work. First, there would be far less justification for finding linkage on the basis of scope in our hypothetical than in American Trucking Assns. To be sure, the property tax reduction benefits all in-state truckers, for in-state truckers by definition own in-state personal property. But the property tax reduction also would benefit every other personal property owner, including any out-of-state trucker that owned personal property of any kind within the state. Even more important, our hypothetical property-tax-relief case involves little, if any, correlation, because large numbers of property taxpayers receive various forms of tax relief wholly unrelated to the amount of each axle tax assessment. This combined lack of correlation and scope - particularly when coupled with the patent lack of internalization in such a case would press hard against finding linkage. In short, this form of tax restructuring would not violate the dormant Commerce Clause even though the property tax reduction would soften the blow for in-state truckers of the newly imposed, nondiscriminatory truck axle tax.

It bears reemphasis that tax restructuring cases do differ from both tax-exemption or tax-credit cases and outright-payment cases. In this respect we agree with Justice Scalia's treatment of the subject in American Trucking Associations. ${ }^{303}$ In contrast to Justice Scalia, however, we do not believe that this difference means that tax-restructuring cases can never give rise to a finding of unconstitutional tax discrimination. In particular, we are inclined to say that the state engaged in unlawful tax discrimination in American Trucking Associations. The presence in that case of simultaneity, 
universality of scope, and strong correlation - together with the state's reduction of a tax traditionally and widely imposed by states throughout the nation (that is, the truck registration tax) - leads us to suspect that an unconstitutional linkage existed.304 At the least, we can say that only minor changes in the facts of the case - for example, the establishment of stronger correlation by way of legislatively imposed durational connection - would lead us to find a constitutional violation.

\section{CONCLUSION}

This article has offered a look at a previously unexplored, but practically important, realm of constitutional tax law: what we call the "law of linkage." The article reveals that important issues concerning the interaction of government spending and taxing measures arise in applying such differing constitutional restrictions as the dormant Commerce Clause, the intergovernmental tax immunity doctrine, and state constitutional limits on nonuniform and unequal taxation. This article also shows that linkage problems lurk in widely differing forms of state action: the simple grant of a tax credit or exemption from a generally applicable tax; the grant of a credit against one tax for payments made on another; the grant of a credit against a tax funded in an identifiable way by the proceeds of some other tax; the grant of tax rebates; the grant of state subsidies or other payments; and the restructuring of a tax system through the repeal or reduction of one tax in connection with the enactment and imposition of another. This article has suggested that, in all these cases, identifiable criteria should - and probably, in an unacknowledged way, do - determine whether a sufficiently close linkage exists between an ostensibly neutral tax and a purportedly independent "spending" measure to trigger application of constitutional tax-discrimination rules.

Key linkage criteria include what we call "internalization" (the state's explicit affording of relief from a tax itself); "simultaneity" (enactment of the taxing and spending measures at the same time); "scope" (the affording of relief by way of the spending measure to all, and only for all, members of the group of not-to-be-favored taxpayers); "correlation" (the durational, computational, or sourcebased alignment of the statutory taxing and spending formulas); and policy responsiveness (the triggering by the challenged state

304. See Richard B. Collins, Economic Union as a Constitutional Value, 63 N.Y.U. L. REv. 43, 92 n.288 (1988) (noting that "Pennsylvania's action departed from established interstate accommodations on truck registration fees"). 
program of specialized policy concerns that underlie the particular tax-discrimination doctrine involved in the case).

By closely analyzing a number of real and hypothetical cases, we have illustrated how these linkage factors should interact in differing legal settings. In the end, however, we are far less concerned with advocating results in particular cases than with advancing the broader objective of encouraging courts to articulate their reasoning in linkage cases. Given the primitive - indeed, virtually nonexistent - state of the law of linkage, what is desperately needed at this juncture are judicial opinions that address linkage issues with reasoned explications that recognize and deal with the difficulties these cases present. It is our hope that this article will help spur such efforts by the courts, for they alone can bring more rationality and stability to this much-unsettled area of the law. 